\title{
Guidelines for the monitoring of Lucanus cervus
}

\author{
Marco Bardiani ${ }^{1,2}$, Stefano Chiari ${ }^{1,3}$, Emanuela Maurizi ${ }^{1,3}$, Massimiliano Tini \\ Ilaria Toni ${ }^{2}$, Agnese Zauli ${ }^{1,3}$, Alessandro Campanaro ${ }^{1,2}$, \\ Giuseppe Maria Carpaneto ${ }^{3}$, Paolo Audisio ${ }^{4}$
}

I Consiglio per la ricerca in agricoltura e l'analisi dell'economia agraria - Centro di ricerca Difesa e Certificazione, Via di Lanciola 12/a, Cascine del Riccio, 50125 Firenze, Italia 2 Centro Nazionale per lo Studio e la Conservazione della Biodiversità Forestale "Bosco Fontana" - Laboratorio Nazionale Invertebrati (Lanabit). Carabinieri. Via Carlo Ederle 16a, 37126 Verona, Italia 3 Università Roma Tre, Dipartimento di Scienze, Viale Guglielmo Marconi 446, 00146 Roma, Italia 4 Università di Roma "La Sapienza", Dipartimento di Biologia e Biotecnologie "Charles Darwin”, Via A. Borelli 50, 00161 Roma, Italia

Corresponding author: Marco Bardiani (bardianimarco@gmail.com)

Academic editor: P.F. Roversi | Received 13 March 2017 | Accepted 5 July 2017 | Published 28 August 2017

http://zoobank.org/8626679B-54AF-4FOB-91A5-C38239E9E8BA

Citation: Bardiani M, Chiari S, Maurizi E, Tini M, Toni I, Zauli A, Campanaro A, Carpaneto GM, Audisio P (2017) Guidelines for the monitoring of Lucanus cervus. In: Carpaneto GM, Audisio P, Bologna MA, Roversi PF, Mason F (Eds) Guidelines for the Monitoring of the Saproxylic Beetles protected in Europe. Nature Conservation 20: 37-78. https:// doi.org/10.3897/natureconservation.20.12687

\begin{abstract}
Lucanus cervus is one of the most charismatic saproxylic beetles, widely distributed in Europe. The species is typical of mature deciduous forests, especially oak woodlands. Loss and fragmentation of suitable habitats is one of the major threats for this species which is included in Annex II of the Habitats Directive. Despite several studies carried out in the last years for the monitoring methods of the species, an analytical comparison between them is still lacking.

The aims of this paper are (i) to review the current knowledge about systematics, ecology and conservation practices on L. cervus and (ii) to present the research carried out during the Life MIPP project, in order to define a standard monitoring method with a suitable protocol to be used for addressing the obligations of the Habitats Directive. Overall, five methods were tested during three years in two different study areas. Based on these results, a suitable standard method for L. cervus is proposed in this paper and, in order to assess the conservation status of populations and to compare them over time, a simple method for the calculation of a reference value is provided.
\end{abstract}

Copyright Marco Bardiani et al. This is an open access article distributed under the terms of the Creative Commons Attribution License (CC BY 4.0), which permits unrestricted use, distribution, and reproduction in any medium, provided the original author and source are credited. 


\section{Keywords}

Habitats Directive, saproxylic beetles, Coleoptera, Lucanidae, monitoring methods, forest biodiversity, sightings along transect

\section{Introduction}

Lucanus cervus (Linnaeus, 1758), belonging to the family Lucanidae, is the largest saproxylic beetle in Europe. Populations of this species inhabit mature deciduous forests, especially the lowland and medium-altitude oak woodlands having rotten dead wood at ground level. Lucanus cervus is considered a flagship species and is included in Annex II of the Habitats Directive (Council Directive 92/43/EEC of 21 May 1992 on the conservation of natural habitats and of wild fauna and flora). The Habitats Directive provides that Member States prepare, every six years, a report on the conservation status of the species listed in the Annexes. In order to address this obligation, the Life Project "Monitoring of insects with public participation" (LIFE11 NAT/IT/000252) (Mason et al. 2015) (hereafter, MIPP) conducted experimental fieldwork to develop a standardised method for the monitoring of the saproxylic beetle species of the project: Osmoderma eremita (hermit beetle, Scarabaeidae), Lucanus cervus (European stag beetle, Lucanidae), Cerambyx cerdo (great capricorn beetle, Cerambycidae), Rosalia alpina (rosalia longicorn, Cerambycidae), Morimus asperlfunereus (morimus longicorn, Cerambycidae).

The present paper is part of a special issue on the monitoring of saproxylic beetles protected in Europe and is dedicated to L. cervus. Therefore, it starts with an indepth revision of the current knowledge on systematics, distribution, ecology, ethology and conservation. The review is followed by a detailed account of the fieldwork carried out during the project and concludes with the description of the proposed monitoring method.

\section{Systematics and distribution}

Lucanus Scopoli, 1763 is a genus of scarabaeoid beetles of the family Lucanidae (stag beetles), subfamily Lucaniinae. The family includes about 1,700 species distributed worldwide (Fujita 2010, Bartolozzi et al. 2014). The holarctic genus Lucanus accounts for some 70 species, mostly in Eurasia, from the Iberian Peninsula to Japan and Indochina. Taxonomy and phylogeny of the genus are far from being fully resolved and several species are difficult to separate from closely related taxa.

In Europe, following the most recent taxonomic reviews (Bartolozzi et al. 2016a, 2016b), five different species have so far been recorded (Figure 1): Lucanus barbarossa Fabricius, 1801 (previously in the discussed subgenus Pseudolucanus Hope \& Westwood, 1845; Iberian Peninsula and northwestern Africa, reaching northwards to the extreme SW France); L. cervus (Linnaeus, 1758) (most of Europe); L. pontbrianti Mul- 

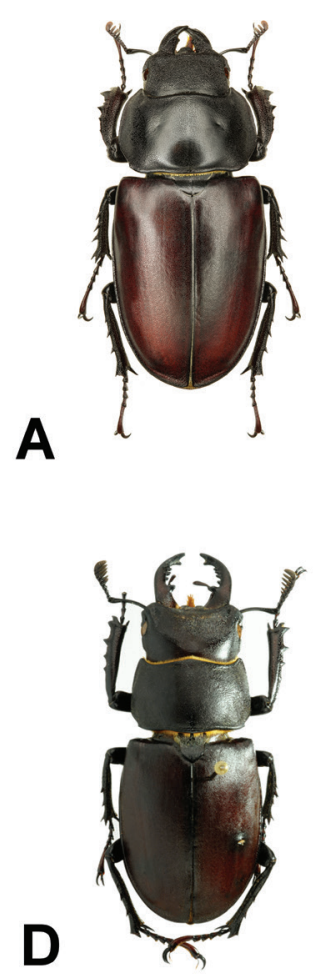

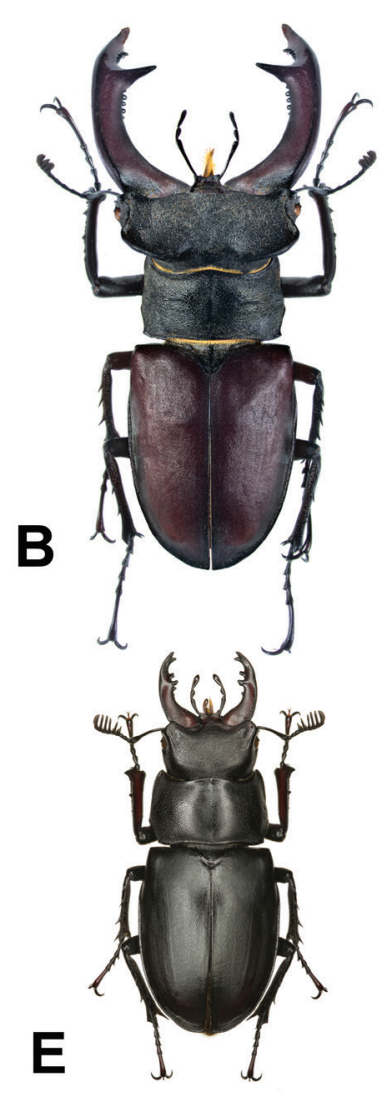

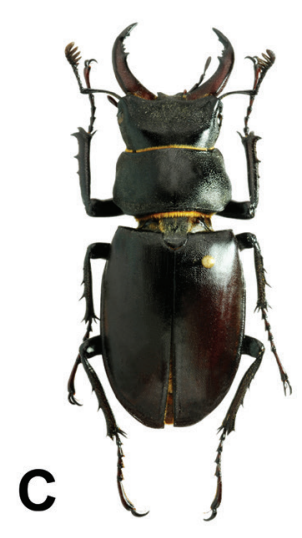

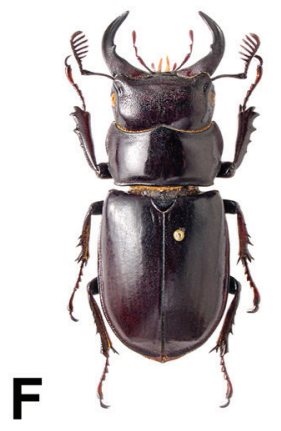

Figure I. The five European species of Lucanus: A L. cervus female (Dresden, Germany; photo by I. Belousov) B L. cervus male (Schweinfurt, Germany; photo by U. Schmidt) C L. pontbrianti male (La Cadière, France; photo by S. Bambi and L. Bartolozzi) D L. tetraodon male (Cosenza province, Italy; photo by S. Bambi and L. Bartolozzi) E L. ibericus male (Dagestan, Russia; photo by I. Belousov) F $L$. barbarossa male (N Spain; photo by M. Zilioli).

sant, 1839 (central-southern France and N Spain; only recently considered a distinct species, clearly separated from the related L. cervus: see Tronquet 2014, Fernández de Gamboa and Garzón 2009); L. tetraodon Thunberg, 1806 (Peninsular Italy, Corsica and Sicily, with old records from Sardinia and relict populations in NE Spain (Atarés) and S France (Janas Forest); also mentioned from Algeria and even the Balkans, probably confused with the next species); L. ibericus Motschulsky, 1845 (Albania, Greece, Turkey, Caucasus, eastwards to Iran).

In particular, L. cervus, is widely spread throughout Europe, reaching northwards to the southernmost counties of Great Britain and Sweden, and southwards to the northern parts of the Iberian Peninsula, the central regions of the Italian peninsula, the Greek mainland and Anatolia (Franciscolo 1997, Bartolozzi and Sprecher-Uebersax 2006, Harvey et al. 2011a). The eastern and southeastern borders of its range are 
not well known as the taxonomic status of the populations of Near and Middle East has still to be defined. The easternmost populations seem to extend to the Caucasus mountain slopes while the southernmost populations find their last refuges in some elevations of the Levant (Franciscolo 1997, Bartolozzi and Sprecher-Uebersax 2006, Harvey et al. 2011a, Cox et al. 2013, Bartolozzi et al. 2016a, 2016b). Further molecular analyses are certainly needed on these eastern populations to better understand their actual taxonomic position. As for taxonomic problems involving the correct identification of certain populations of $L$. cervus and L. tetraodon from Central Italy, refer to Solano et al. (2016), and to the discussion in the paragraph "Identification and comparison with similar taxa". In fact, $L$. tetraodon replaces $L$. cervus in southern Italy, Corsica and Sicily (Miksic 1959a, 1959b, 1961, Franciscolo 1997, Lapiana and Sparacio 2006, Santoro et al. 2009) but there is a well-documented area of overlapping in central Italy, where the two species often live in syntopy (Bartolozzi 1986, Bartolozzi and Maggini 2007, Cortellessa et al. 2014, Solano et al. 2016) and many specimens (purported to be hybrid) exhibit intermediate morphological characters between the two species (Santoro et al. 2009). In the last dozen years, some records of L. tetraodon in Emilia-Romagna (Fabbri 2010), Liguria (Bartolozzi and Maggini 2007) and Lombardy (Zilioli and Pittino 2004) have extended the Italian distribution range northwards, while in Sardinia, the species has not been found recently (Carpaneto et al. 2011b).

A summary of the Italian localities reported for both L. cervus and $L$. tetraodon is presented in Figure 2.

\section{Morphology}

The larval instars of the stag beetles do not differ substantially in shape but show a marked increase in size: from $5 \mathrm{~mm}$ of a new born larva, up to $10-11 \mathrm{~cm}$ in length of the last larval instar (Franciscolo 1997, Percy et al. 2000). The larva hatches from a subspherical (4 $\mathrm{mm}$ in diameter) and ivory coloured egg (Figure 3). The typical Lucanid larva (Figure 3) is whitish or creamy, soft, oligopod, roughly "C-shaped" in lateral view, without transverse folds in the abdominal segments and with a longitudinal anal slit. Head capsule is large, from reddish-brown to orange, more sclerified than body. Ocelli and ommata are absent, antennae rather elongated and pubescence only just developed in the anterior portion of body. The nine pairs of spiracles are moderately developed (the first one is larger and wider than the others), roughly "C-shaped" (Figure 3). Larvae have a typical stridulatory apparatus, formed by two sclerified organs on the second and third leg pairs respectively. A pair of soft, gibbose and translucid oval protuberances, occurs at the abdominal apex in dorsal-posterior view (Figure 3), these being larger and closer to each other in their inner portions, in Lucanus, when compared with those present in the much smaller larvae of the lucanid genus Dorcus MacLeay, 1819. The ventral side of the distal abdominal portion of larvae exhibits a large group of short brownish bristles (widely convergent to form a roughly "U-shaped" figure), 


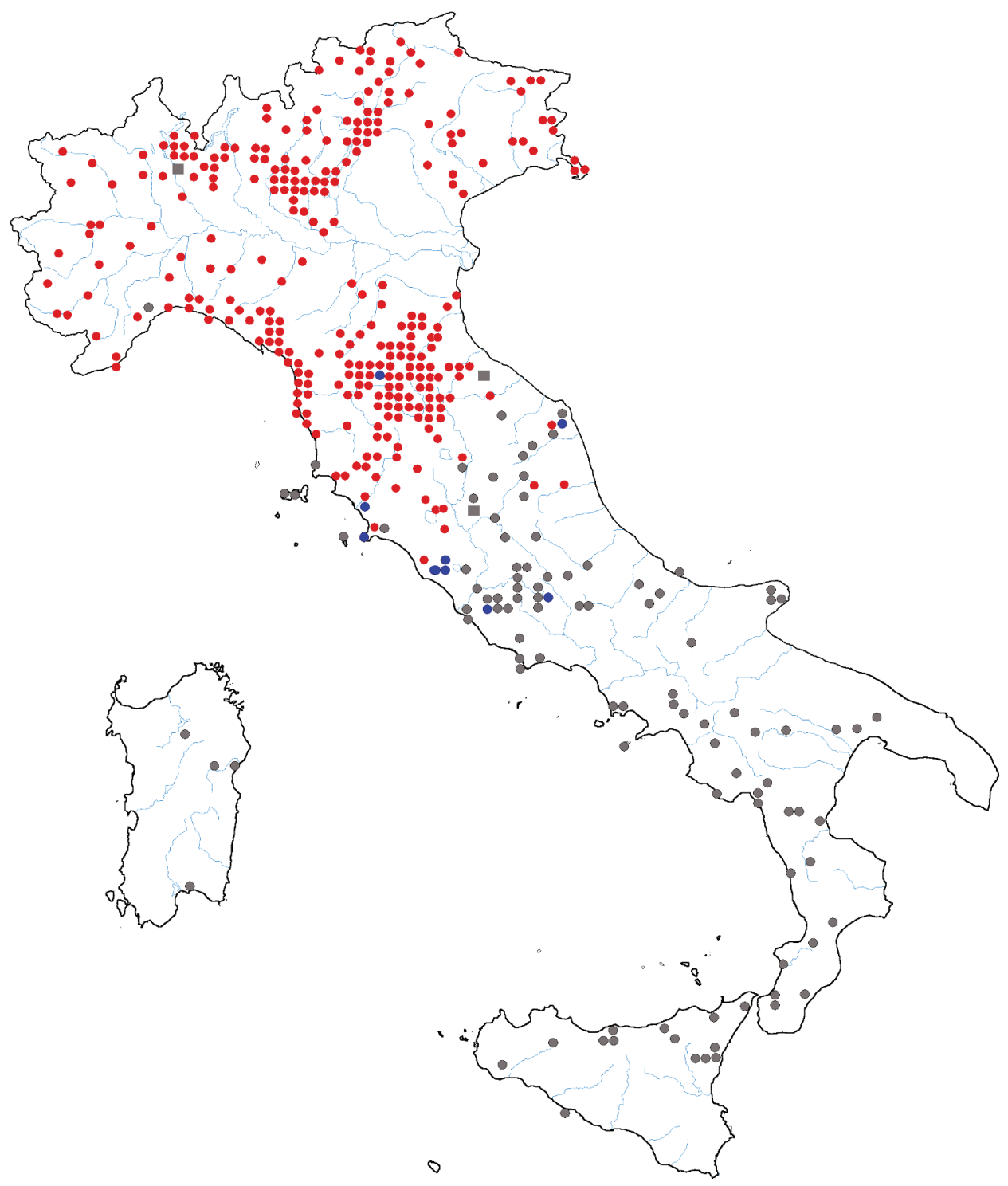

Figure 2. Distribution in Italy of the Lucanus species (red dots: L. cervus; grey dots: L. tetraodon; blue dots: both species; grey squares: recent data of L. tetraodon by Zilioli and Pittino 2004, Fabbri 2010). (Bartolozzi and Maggini 2007, modified by the Authors).

much denser, stronger and numerous than in Dorcus. Additionally, the mandibles of Lucanus larvae are larger and more curved distally, while those of Dorcus are smaller and almost parallel-sided (Figure 4).

The pupa is exarate, i.e. showing free appendices, including the large mandibles of the adult males (Figure 3). 


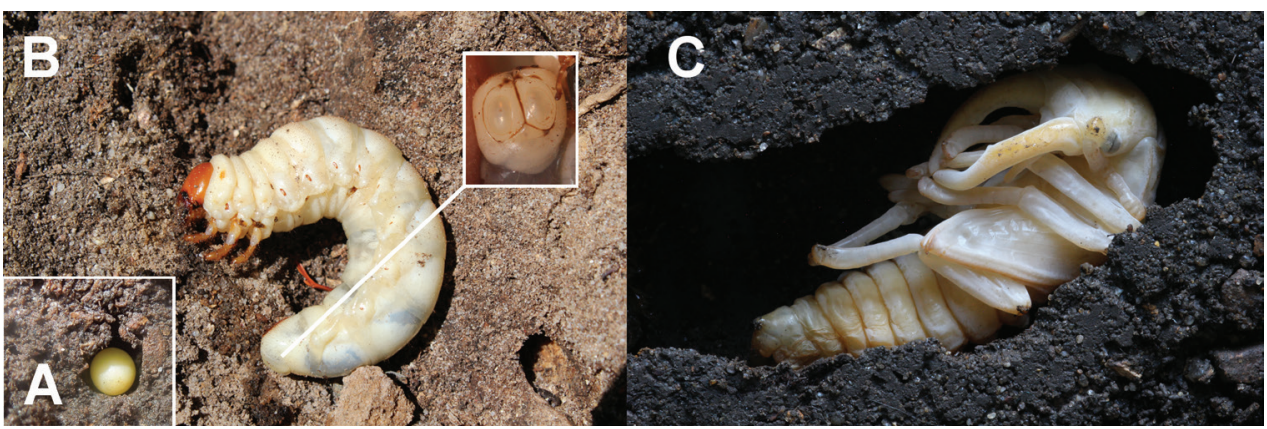

Figure 3. Pre-imaginal stages of Lucanus cervus: A egg (photo by C. Molls) B mature larva in lateral view (photo by M. Przewoźny) and detail of the apex of the abdomen in posterior view (photo by M. Fremlin) C Pupa of a male in lateral view (photo by M. Fremlin).

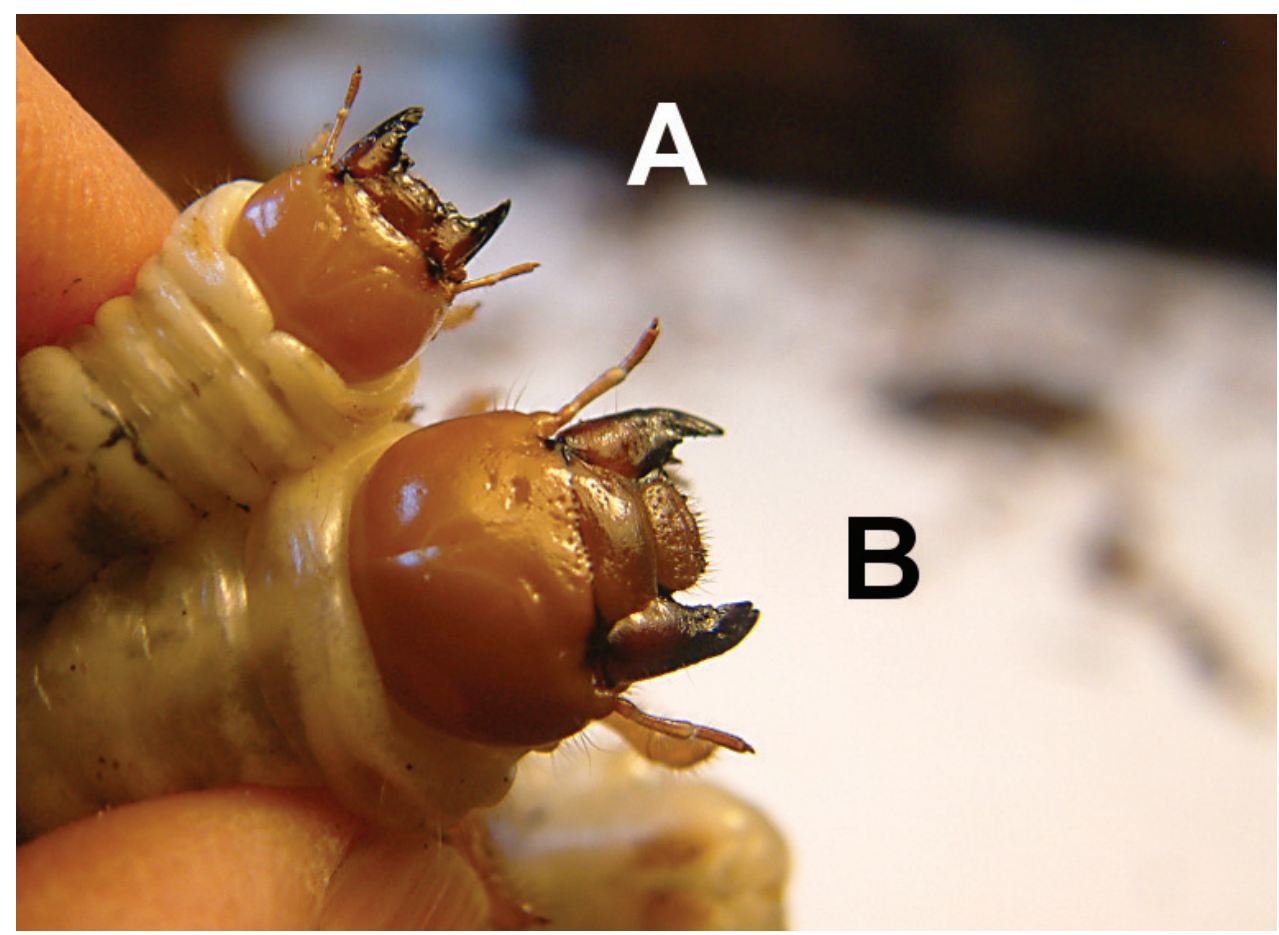

Figure 4. Head capsule, mandibles and relative size of lucanid larvae: A Dorcus parallelipipedus B Lucanus cervus (photo by M. Fremlin).

Adults of $L$. cervus, chiefly males, exhibit a strong morphological variability in shape and size of several characters, more or less uniformly expressed throughout the whole geographic range of the species, as shown in Figure 5.

These adults are $25-89 \mathrm{~mm}$ long (ca. $25-49 \mathrm{~mm}$ in females; ca. $30-89 \mathrm{~mm}$ in males), including the mandible length. The colour varies from reddish-brown to very 


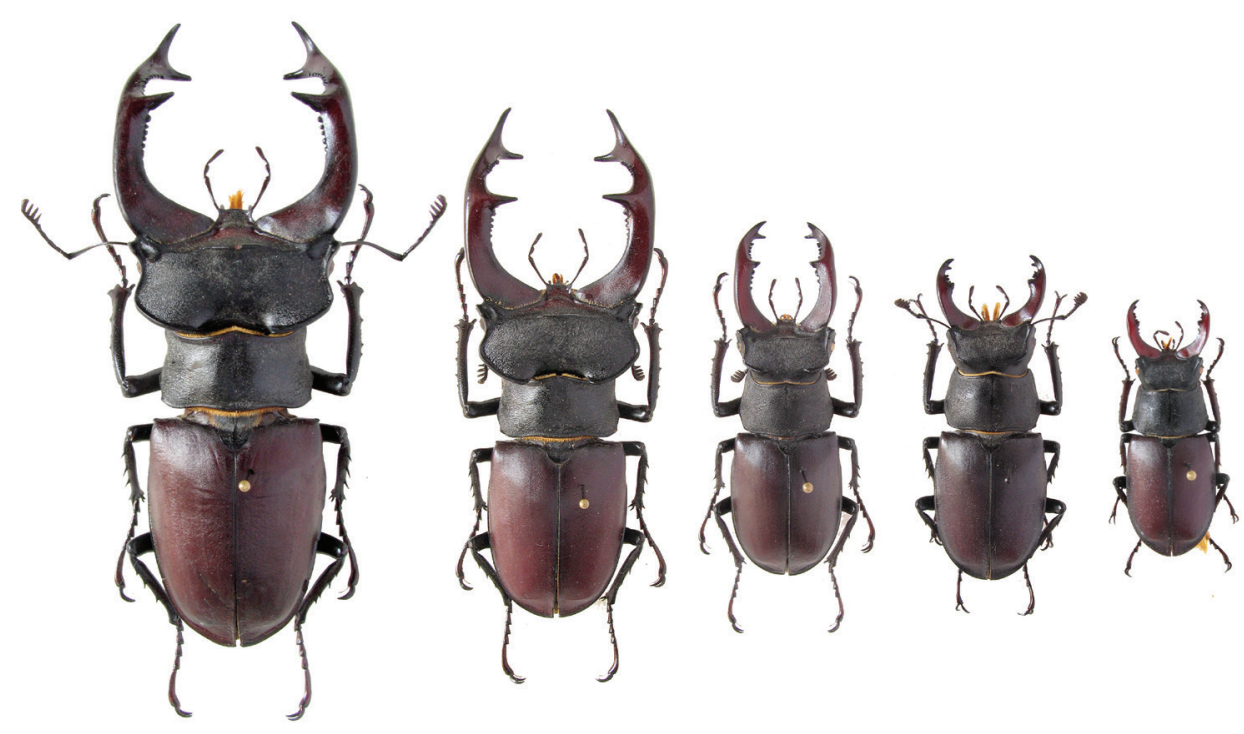

Figure 5. Polymorphism in Lucanus cervus males (all specimens from northern Italy; photo by M. Zilioli).

dark brown, almost black. Frequently, males exhibit reddish elytra and mandibles contrasting with the dark colour of the other body parts, even though the smallest specimens are more uniformly and blackish coloured. The antennal club exhibits four (or more rarely five) antennomeres, usually more abruptly enlarged when compared to the last antennomere just before the club. The species exhibits a strong sexual dimorphism: the male has large mandibles, longer than its head, while the female has much shorter mandibles, not longer than its head.

In males, the mandibles of $L$. cervus are characterised by the position of the largest inner tooth which lies in the distal half of the mandible or close to the middle of the mandible. Using a traditional morphometric approach, Romiti et al. (2015) highlighted the presence of two morphological classes: large males (which invest significantly more in mandibles and head size) and minor males. Furthermore, a geometric morphometric approach revealed that smaller males show highly variable mandibles (usually less curve dorsoventrally, thickset, with barely outlined teeth and a head without prominent basal edges) whereas larger males exhibit less variable mandibles (slender and equipped with fully developed median teeth, and deep, divaricate apical forks, supported by wide head basal edges) (Romiti et al. 2016).

\section{Identification and comparison with similar taxa}

The genus Lucanus is easily distinguishable from all other genera of European Lucanidae, while the specific distinction amongst closely related congeneric species is often 
problematic (Figure 1). Hereinafter a brief comparison of the five Lucanus species is presented, mainly focused on male diagnostic features.

Lucanus tetraodon (Figure 1), is on average smaller (26-52 $\mathrm{mm}$ in length) than L. cervus, as well as the size of the mandibles in males. The position of the largest inner tooth lies in the proximal half of the mandible, sometimes very near to the base. The antennal club is usually made up of the last 5 or 6 (rarely 7 ) antennomeres, gradually enlarged, when compared to the last antennomere just before the club. As discussed above, these characters are not always diagnostic (see Figure 6) in central Italy where $L$. cervus and $L$. tetraodon frequently overlap and probably exhibit phenomena of past hybridisation (Solano et al. 2016). This phenomenon occurs mostly in areas between the provinces of Viterbo and Rome in Latium, as well as between the provinces of Perugia and Terni in Umbria. In this geographic area, there are very large intermediate individuals with huge mandibles (such as in larger $L$. cervus specimens) but with five or six antennomeres in the club and with the last inner tooth near to the mandible base (as is usual in L. tetraodon). In addition, the shape of the male genitalia is not very useful for distinguishing the two species, although they always appear markedly separated by molecular analyses, even when apparently "intermediate" sympatric forms are analysed. In fact, most "intermediate" specimens from central Italy univocally resulted in being $L$. cervus from a molecular point of view (Solano et al. 2016; Figure 6).

Lucanus pontbrianti (Figure 1) is $25-55 \mathrm{~mm}$ in length. The mandibles of the males are smaller than males of $L$. cervus, as well as the inner tooth, positioned between the middle and the distal third of the mandible. Additionally, the distal portion of the mandibles is much more slender, with apex almost simple or only minutely and obtusely forked than $L$. cervus. Finally, in the males of $L$. pontbrianti, the antennal club is proportionally markedly larger and longer than in L. cervus and made up of the last 5-7 antennomeres.

Lucanus ibericus (Figure 1) is $27-51 \mathrm{~mm}$ in length. The mandibles of the males have usually smaller and more slender distad than L. cervus, with apex not markedly forked. The inner tooth is positioned near to the middle of the mandible. The most relevant diagnostic character between the two species is perhaps represented by the relative size of the antennal club, its length being ca. 1/4-1/5 of the fore tibiae in males in L. cervus (where it is made up of the last 4 or 5 antennomeres), while it is usually much larger (made up of the last 6 antennomeres) and a little shorter than 1/2 of the fore tibiae in males of $L$. ibericus.

Lucanus barbarossa (Figure 1) is on average smaller (28-48 $\mathrm{mm}$ in length) than $L$. cervus. The mandibles are almost without teeth along their inner edge and their distal portion is much more slender and almost simple, arcuately pointed. L. barbarossa exhibits a larger relative size of the antennal club (coupled with distinctly shorter antennal scape); its dorsal body surface is much shinier, the pronotum is more arcuately shaped at sides and the anterior portion of the head between the eyes and the base of the mandibles is proportionally longer and much more regularly and arcuately shaped than in L. cervus. 


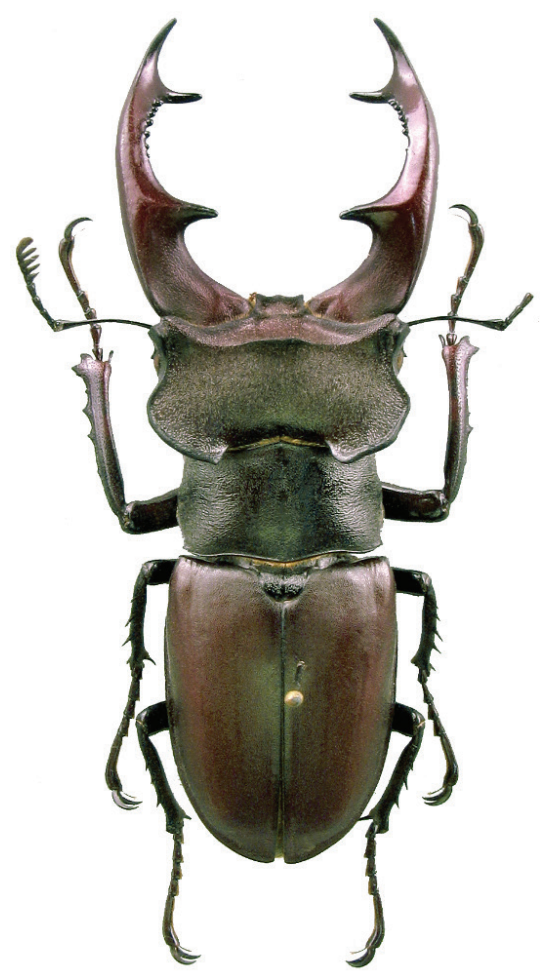

Figure 6. L. cervus from a contact area with L. tetraodon in Central Italy (Northern Latium, northern Rome province, Manziana; photo by M. Zilioli).

\section{Ecology}

Lucanus cervus inhabits mature deciduous forests, especially the lowland and mediumaltitude oak woodlands (Campanaro et al. 2011a) but can also occur in urban habitats (e.g. city parks, private gardens) (Franciscolo 1997, Hawes 2008, Harvey et al. 2011a). The altitudinal range varies from sea level to $1,000 \mathrm{~m}$ a.s.l. (Campanaro et al. 2011a), it has been reported up to $1,700 \mathrm{~m}$ in Bulgaria (Harvey et al. 2011a).

The larvae are xylophagous, feeding on rotten dead wood at ground level (e.g. under stumps and fallen logs or amongst the roots of standing dead trees) (Franciscolo 1997, Campanaro et al. 2011a). In urban habitats, the larvae can also be found in small wood sources (e.g. bark chippings, fence posts, railway sleepers) (Harvey et al. 2011a). A massive suitable habitat can be exploited by several generations of larvae for several years, until the complete disintegration of it (Franciscolo 1997).

The host plants of the larvae belong to the genera Quercus, Fagus, Salix, Populus, Tilia, Aesculus, Ulmus, Pirus, Prunus and Fraxinus (Franciscolo 1997) but also Castanea, Alnus and Pinus (Harvey et al. 2011a). Amongst these, oaks and in particular, the English oak (Quercus robur), seem to be their favourites (Harvey et al. 2011a) and 
Tini et al. (2017a) reported that $L$. cervus can also develop within suitable substrates of the allochthonous northern red oak (Quercus rubra).

Two species belonging to Diptera Phoridae, Megaselia rufipes (Meigen, 1804) and Aphiocheta rufipes (Meigen, 1830), were reported by Franciscolo (1997) as parasitoids of the stag beetle larvae. Although some mites can attack larvae and pupae, they tend to pursue adult stag beetles when they are still within their emergence galleries (Franciscolo 1997).

The main predators of larvae and pupae of stag beetle are the wild boar (Sus scrofa) and the badger (Meles meles) (Harvey et al. 2011a, Chiari et al. 2014).

The imagines of $L$. cervus usually emerge from the ground in May and males about a week before females (Harvey et al. 2011a). Emergence is influenced by local climate and can occur early (late April) or later, e.g. in cooler countries such as Sweden or regions with wet springs such as Switzerland (Harvey et al. 2011a). The phenology of the species has been described in several studies carried out in Europe, mainly related to specific monitoring methods (e.g. collection of remains of predation or sightings along a transect). In Belgium, adults have been sighted from the end of June to the second half of August (Campanaro et al. 2016). In Germany, Rhineland-Palatinate region, adults have been found from mid-May to mid-June (Rink and Sinsch 2011). Data from Italy showed a restricted or expanded phenology in 3 distinct areas: western Alps (329-622 m a.s.l.) from mid-June to mid-July (Chiari et al. 2014), northern Apennines (about $700 \mathrm{~m}$ a.s.l.) from the last week of June to the first week of August (present work) and central Po plain (about $25 \mathrm{~m}$ a.s.l.) from mid-May to the second half of August (Campanaro et al. 2011b, Corezzola et al. 2012). Data gathered by citizens (Campanaro et al. 2017), showed an overall phenology of the species for the whole of Italy from the beginning of May to the beginning of September. In Poland, Campanaro et al. (2016) reported data from mid-June to mid-August. In Slovenia, Vrezec (2008) analysed data from the first half of May to the second half of August (but only few and isolated data between the end of March and the first half of April and for the second half of September have also been reported). In Spain, Asturias region, Álvarez Laó and Álvarez Laó (1995) reported data from the second half of June to the first half of September. Campanaro et al. (2016), for the central Iberian region (Guadarrama Range), reported data from the beginning of June to the second part of July. In Switzerland, Sprecher-Uebersax and Durrer (1998), reported data from May to July. In the United Kingdom, Harvey et al. (2011b) reported data from the last week of May to the first week of August.

The adults are mainly active at dusk and there is a seasonal peak of activity, related to the night swarming of males which are seeking females for mating (Franciscolo 1997). This peak can vary from the end of May (beginning of June) to the end of June (Campanaro et al. 2016). In Italy, data from northern Apennines show a later peak of activity, close to mid-July (present work).

The flight arrangement is characteristic: the males (and mainly the "majors", with large mandibles) keep the body close to the vertical position to balance head weight and fly slowly along straight lines (few corners and wide-ranging) with several height 
variations; females, characterised by a small head armed with a short mandible, keep the body much less vertical (Franciscolo 1997). Take off requires a vertical position above ground, such as from the trunk and branches of trees or shrubs (Rink and Sinsch 2007). Flights will be avoided during heavy rain or strong winds (Campanaro et al. 2011a). Concerning temperature, Rink and Sinsch (2007) observed that stag beetles are able to fly within a range of $11^{\circ} \mathrm{C}$ to $26^{\circ} \mathrm{C}$ and inferred that their flight was hindered over $27^{\circ} \mathrm{C}$. Harvey et al. (2011a) reported a mean threshold temperature for flight of $14.32^{\circ} \mathrm{C}$ (temperature range: $11-18^{\circ} \mathrm{C}$ ). A recent radiotelemetric study at Bosco della Fontana, reported flying events within a temperature range of $18-28.7^{\circ} \mathrm{C}$ and a humidity range of 49-92.9\% (Tini et al. in press).

About vertical use of space, females usually stay at ground level while males are more often sighted in flight, up to the canopy layer (Franciscolo 1997, Harvey and Gange 2006, Campanaro et al. 2016, Bardiani et al. 2017). Nevertheless, capture data for females found in canopy have also been reported (Bardiani et al. 2017). Both sexes feed on sap runs on tree trunks or on sugary substances (Franciscolo 1997, Fremlin and Hendriks 2011, Harvey et al. 2011a, Jansson 2011, Trizzino et al. 2013, Bardiani et al. 2017).

When more than one male detect a female, they fight amongst themselves (Franciscolo 1997). If body size of males is an advantage in a fight, it is not always the case in mating success (Franciscolo 1997, Harvey and Gange 2006). In fact, mating success depends on the "male:female" body size ratio (optimum value: 1.4) as the larger males are often unable to breed with females (Harvey and Gange 2006). Many vertebrates are predators of adult stag beetles, such as the shrew (Sorex araneus), fox (Vulpes vulpes), magpie (Pica pica), hooded crow (Corvus corone cornix), woodpeckers, kestrel (Falco tinnunculus) and owls (Franciscolo 1997, Campanaro et al. 2011b, Harvey et al. 2011a). Predation by the Eurasian jay Garrulus glandarius was observed in two localities of central Italy (Audisio and Carpaneto, unpublished data). Recently, Fremlin (http://maria.fremlin.de/stagbeetles/spiders.html, 2015, accessed 27 September 2016) reported predation of $L$. cervus by the false widow spider (Steatoda nobilis).

After mating, the female digs a deep gallery (up to $70-100 \mathrm{~cm}$ ) into the soil, close to suitable substrates for larval development (e.g. tree roots, rotten wood) (Franciscolo 1997, Harvey et al. 2011a). The clutch size is about twenty eggs (Franciscolo 1997) with a range of 15-36 eggs (Harvey et al. 2011a). Females can carry out more rounds of oviposition, producing a total of 50-100 eggs (cf. Franciscolo 1997) and they can choose additional nest sites (Tini et al. 2017a, 2017b). Lucanid females release a secretion (housed in a structure called mycangium) near the laid eggs (Tanahashi et al. 2010). The secretion contains yeast that will be eaten by the larvae during their first meal: in this way, the larvae acquire yeast for the digestion of wood. After the last oviposition, the female does not re-emerge from the ground but she dies in situ (see Franciscolo 1997).

Data about larval and pupal stages (e.g. number and duration of instars) are difficult to obtain in nature or related to incidental occasions (Harvey et al. 2011a). The majority of available data come from captive beetles whose breeding is obtained by simulating their natural habitat conditions. 
The incubation time for eggs varies from 14 (cfr. Franciscolo 1997) to 45 days (Harvey et al. 2011a). After this time, a small larva hatches using its mandible to break the eggshell (Franciscolo 1997). Larva usually develops in four years (range between 3 and 6 years) (Harvey et al. 2011a), through 3 instars (Fremlin and Hendriks 2014). Franciscolo (1997) also reports a higher duration for larval development, in particular for specimens of larger dimensions, whereas Fremlin and Hendriks (2014) reported some cases of a shorter duration ( 2 years). At the end of its development, the larva moves from the wood to the soil (at $20 \mathrm{~cm}$ depth) where it builds a cocoon (of soil and sand) for its pupation. During the preparation of the cocoon, the larva lines the wall with secretion from its gut (Hendriks and Fremlin 2012) and spreads the symbiotic yeasts (Fremlin and Tanahashi 2015). After hatching, the female everts the mycangium and sweeps the abdomen: this movement allows the mycangium to touch the cocoon wall and take up symbiotic yeasts (Fremlin and Tanahashi 2015). The pupal stage lasts on average 44 days (range from 28 to 60 days) at the end of summer: from the end of July by Harvey et al. (2011a), from the end of August by Franciscolo (1997). The adult is completely formed in autumn but it overwinters inside the cocoon and emerges from the ground in spring (Franciscolo 1997). The duration of the adult active period varies from a few weeks up to three months: Harvey et al. (2011a) reports an average period of 8 weeks for the males (range of 6-10 weeks; data from 9 countries) and 12 weeks for females (range of 8-14 weeks; data from 9 countries). Males of adult stag beetles, breeding in captivity, survive up to 200 days and female even more (cfr. Franciscolo 1997).

\section{Threats}

Lucanus cervus is protected by the Bern Convention (Annex III) and by the Habitats Directive (Annex II) (L. pontbrianti, recently reconsidered as a valid species by the splitting of $L$. cervus, should also be protected). The species is listed in the Red List of the European saproxylic beetles under the category Near Threatened (Nieto and Alexander 2010). In the Red List of Italian saproxylic beetles (Audisio et al. 2014, Carpaneto et al. 2015), it appears under the category Least Concern, because, on the basis of actual knowledge of the species in Italian territory and following IUCN criteria (such as population abundance and distribution area), the species should not be considered in a critical state. Following Harvey et al. (2011a) the species is rare if the entire range in Europe is considered where it seems to have a negative trend, mainly as a consequence of habitat loss: from comparison of data, taken in different periods, the species appears to be decreasing not for the area of occupancy (number of detection sites and population abundance) but for the extent of occurrence (range size).

According to Nieto and Alexander (2010), L. cervus is threatened principally by the decrease in the mean tree age in forests which is mainly due to intensive management and over-exploitation especially in eastern Europe. The consequence of this is the loss of the forests' dead wood and of old trees which are the required habitats for the species to complete its life cycle. 
A not insignificant threat is due to the increase in predation rate by opportunistic species of birds (magpie, jay and crow) which show a marked demographic growth in anthropogenic environments (Carpaneto et al. 2015).

From the studies of Rink and Sinsch (2011), the rise in temperature could represent another threat to the continuation of stag beetle populations in Europe: hot temperatures above $27^{\circ} \mathrm{C}$ hinder the flight activity of these beetles during the mating season and drought could hamper the emergence of the adults in spring.

\section{Review of monitoring experience in European countries}

During the last years, different methods for the monitoring of $L$. cervus have been tested in many European countries.

The method based on counting the remains of adults killed by vehicles has been used in Spain by Álvarez Laó and Álvarez Laó (1995) and by Proyecto Ciervo Volante (1995). The count of roadkills has also been tested in Belgium (Thomaes 2008) and in the United Kingdom by Hawes (2005) and by Harvey et al. (2011b), with the aim of obtaining presence/absence data for the area and for assessing the local abundance of the species.

Counts of predation remains have been tested in Belgium by Kervyn (2006) (searching on the ground or inside owl pellets) in Germany by Malchau (2006) and in Italy by Campanaro et al. (2011b).

The use of transects for sighting of adults in the evening has been tested in Spain (Proyecto Ciervo Volante 1995), in Bulgaria (Anonymous 2005), in Belgium (Kervyn 2006), in Slovenia (Vrezec et al. 2012), in Italy (Campanaro and Bardiani 2012, Chiari et al. 2014) and in Romania (Fusu et al. 2015).

The counts of living adults have been tested in Germany by Malchau (2006) and in Italy by Chiari et al. (2014) (visual encounter surveys). Another method, consisting of surveys of trunks during the night by counting living adults, has been tested in Slovenia by Vrezec et al. (2012).

Interception traps have been tested in Belgium (Kervyn 2006) and pitfall traps (on the ground and in trees) have been tested in Slovenia by Vrezec et al. (2012).

The use of attractive baits has been associated with different traps. In Spain, GTLI (2005) used interception window traps, pitfall traps and aerial (bottle) traps baited with fruit, slices of ginger or liquids such as wine or beer (for bottle traps). In Germany, Malchau (2006) used traps baited with a mixture of fruit and alcohol. In Slovenia (Vrezec and Kapla 2007) and in Belgium (Thomaes 2008), pitfall traps, baited with fruit and ginger respectively, have been used. In the United Kingdom, Harvey et al. (2011b) tested many different baits (alcoholic and sugary liquids, chemical compounds, fruit, roots, vegetables) using laboratory and field tests (by interception window traps and pitfall traps). In Sweden, different compounds, made from sugar, yeast and enzymes combined with oak leaves or bark, have been tested in the field by Jansson (2011). In Italy, a subset of baits tested by Harvey et al (2011b) has been tested by Chiari et al. (2014) with the same traps, 
whereas Bardiani et al. (2017) tested two different alcoholic-sugary mixtures with aerial (bottle) traps.

Experiments, using acoustic detection of larvae, have been carried out in the United Kingdom by Harvey et al. (2011b) using a technique that requires sophisticated equipment and has not yet been tested in the field.

As the exaggerated mandibles and the large body size of $L$. cervus males enable it to attract people's attention, the stag beetle could be a good subject for educational campaigns and citizen science projects for the conservation of forests and organisms which live inside these habitats (Carpaneto et al. 2015). Since 1994, distribution data for the species have been gathered with the help of citizens in Spain (Proyecto Ciervo Volante 1995) and since 1998, in the United Kingdom (Percy et al. 2000, Smith 2003, 2011). In France, the ONG Office pour les insectes et leur environnement (OPIE) launched another citizen science project for $L$. cervus and gathered the sightings made by people through a web portal. In Switzerland, gathering data during the reproductive season of 2003 confirmed the previous knowledge about the distribution of the species in the Ticino and its phenology in the north-western Alps (Moretti and Sprecher-Uebersax 2004). In the Netherlands, Smit and Krekels (2006), made a public announcement with the aim of collecting observations from people: they provided a distribution map and images of the stag beetle to the public in order that they learn to recognise the species. In Italy, Zapponi et al. (2017) reported the preliminary results about MIPP citizen science, to show the efficacy of citizens' contribution in obtaining reliable data on the distribution of the stag beetle in the country.

Despite the large numbers of national monitoring studies, up to 2010 there have been few collaborative initiatives at international level. A revision of bionomics and distribution of L. cervus was carried out by Harvey et al. (2011a), gathering information from more than forty European and Asian countries and opening the way for the collaborative study published more recently by Campanaro et al. (2016). In this study, carried out by a team of researchers from eight European countries (Belgium, Germany, Italy, Poland, Slovenia, Spain, Switzerland and United Kingdom), a standard monitoring method was used to compare some aspects of the population ecology of the species by using the evening transect method. The study of Campanaro et al. (2016) represented an essential step in the choice of a standard method applicable at European level.

\section{Methods}

At the beginning of the project (see Carpaneto et al. 2017), a selection was made from the known monitoring methods and four methods were selected: Sighting individuals along transects at dusk, Collecting remains of predation along transects, Capturing individuals in selected points at dusk (changed to Capturing individuals along transects at dusk, after the first year) and Baited traps. In order to find the most appropriate 
standard monitoring method (quick, cheap, replicable protocol over the years and in different sites, easy and high detection of the species, high number of contacts in order to assess population abundance), a comparison of the selected methods has been carried out in two different study areas for three years. The methods and the sampling plan are detailed below.

\section{Sighting individuals along transects at dusk}

The method (hereafter: Sightings) is based on transect walks as described by Campanaro et al. (2016). Each transect is $500 \mathrm{~m}$ long and, from the centre of the path, must allow sighting up to $5 \mathrm{~m}$ on both sides (on the whole $10 \mathrm{~m}$ wide). The transect should follow landscape features such as roads, paths or forest edges, where the tree canopy over the whole transect (or most of it) should be sufficiently open to allow acceptable light conditions at dusk (Figure 7). The walk starts 15 minutes before the sunset and lasts 30 minutes on the whole. The $500 \mathrm{~m}$ length is divided into 5 sectors of $100 \mathrm{~m}$, so that each one is walked in 6 minutes. Each "hundred metres' point" is marked with barrier tape on both sides of the transect, so that, during the walk, the operator has a reference point and can check that he/she is on schedule. All specimens observed within the transect are recorded, taking note of the sex of each animal (using the "unknown" option when it is impossible to recognise the sex of a flying uncaptured individual), the sector in which it is sighted, the height of flight $(<2 \mathrm{~m},>2 \mathrm{~m})$ and the relative position on the track (left, centre or right) for both flying and walking individuals. The transects are carried out by one operator and only on days with suitable weather, i.e. without rain (only drizzle is acceptable), without strong wind and with a temperature above $13^{\circ} \mathrm{C}$. For each survey, the transect direction is inverted to avoid the same end of a transect always being visited at the same hour.

\section{Collecting remains of predation along transects}

This method (hereafter: Remains) is based on the search and collection of remains of stag beetles predated by birds or mammals (Campanaro et al. 2011b) and it is similar to the collection of remains of dead specimens, killed by vehicles along road transects (Harvey et al. 2011b). The remains are mainly found after the predation of adult beetles by corvids (jays, magpies or crows) which discard the hardest parts of the exoskeleton. The collection of remains is undertaken along transects such as those previously described for sightings of live beetles. If grasses grow on the path, their height should be low enough to allow easy sightings of the remains (Figure 7). The collection of remains is carried out by one operator during daytime. All remains are collected and preserved dry in paper bags. Each paper bag reports date, identification code of the bag, transect and sector of collection, number of specimens (counting is performed by 


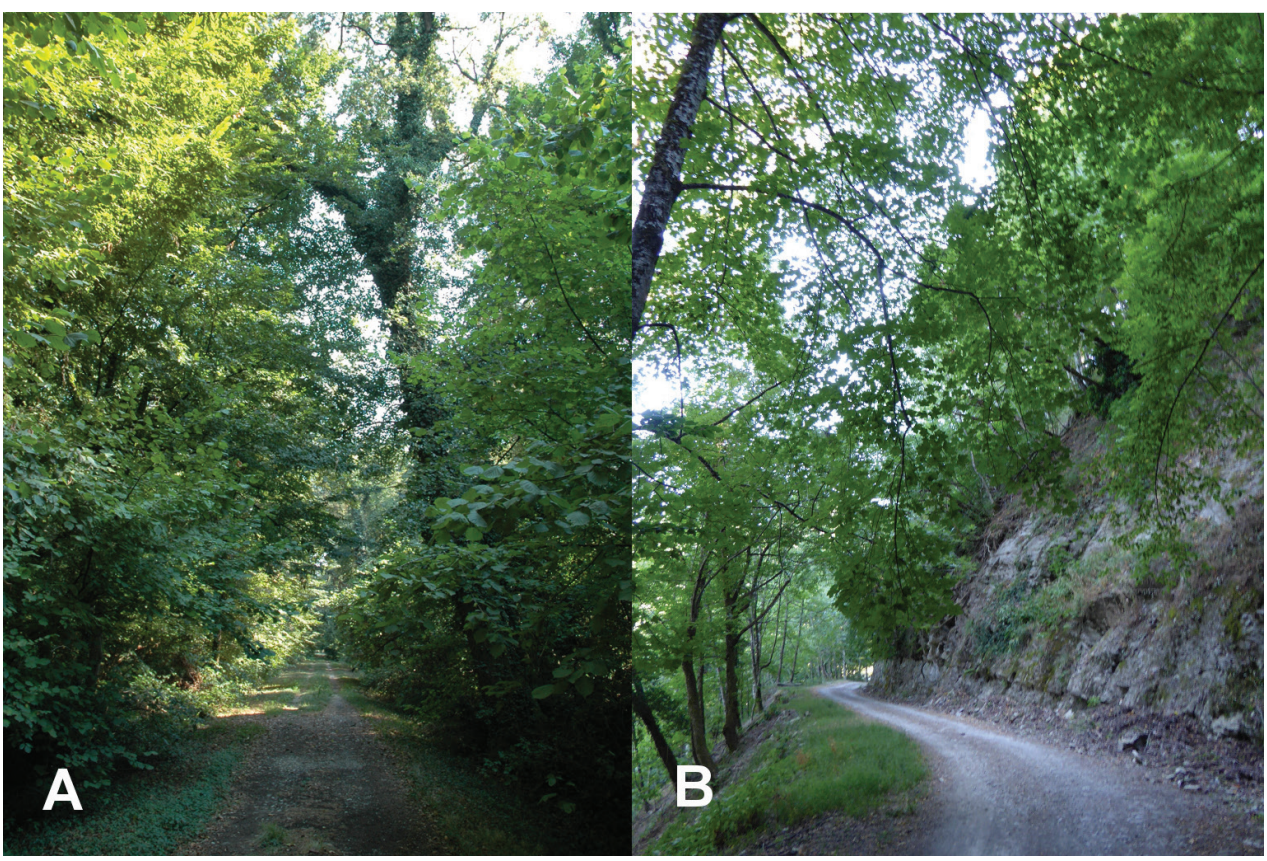

Figure 7. Examples of transect paths: A Bosco della Fontana (photo by I. Toni) B Foresta della Lama (photo by M. Bardiani).

considering all the body parts, reasonably belonging together, as one specimen) and type of remains collected (e.g. elytra, pronotum, head, whole specimens). Date, number of transect, operator, start and end time of transect and position reference of the paper bag along the transect are also reported on the field-sheet.

\section{Capturing individuals along transects at dusk}

The method (hereafter: Net-transect) is based on the live capture of the highest possible number of individuals sighted at dusk along transects. The aim of the capture is to obtain a reliable taxonomic identification for each individual sighted and avoid confusion of L. cervus with other related species where they live together (e.g. L. tetraodon in central Italy). The method is undertaken along transects with the same technical specifications (length, duration, time of the day, direction of the walk) of Sightings. Before starting the walk, containers for temporarily storing the beetles captured in each sector are placed every $100 \mathrm{~m}$ along the transect (at the five ends of each $100 \mathrm{~m}$ run including the final point). Each individual sighted or captured is noted in the same way as described for Sightings. Flying beetles are captured with a net (circular frame diameter: $50 \mathrm{~cm}$; telescopic handle: up to about $2 \mathrm{~m}$ ) while walking beetles are seized by hand. At the end of the whole transect, the operator walks back to take photographs of individuals with doubtful identification and then releases all the beetles into their sector. 


\section{Capturing individuals in selected points at dusk}

The method (hereafter: Net-point) is based on the capture of all individuals sighted, when they rush to swarm in a wide clearing that may represent a place preferred by stag beetles for mating at dusk (Chiari et al. 2014). All individuals are temporarily captured during the collecting survey and kept into separate vials as described for Net-transect method. The equipment of the operator (net and containers) is the same as the previous method Net-transect.

\section{Baited traps}

The method (Bardiani et al. 2017, Redolfi De Zan et al. 2017) is based on baited and aerial traps, previously used by several authors (Allemand and Aberlenc 1991, Mason et al. 2002, Vrezec and Kapla 2007), but modified into non-lethal traps (Campanaro et al. 2011a, Corezzola et al. 2012). Traps (Figure 8) are handmade and consist of two stacked HD polyethylene jars $\left(1,000 \mathrm{~cm}^{3}\right.$ each). The upper jar is the capture chamber and has the lid modified with a plastic funnel (diameter: $10 \mathrm{~cm}$; stem: cut out to create an opening of $4 \mathrm{~cm}$ diameter). The bottom of this upper jar is cut out and connects with the lower jar which contains the bait as a liquid mixture. A $2 \times 2 \mathrm{~mm}$ mesh wire net separates both jars. The wire net prevents specimens entering the trap and falling into the liquid bait. Two mixtures were tested as baits: (i) red wine, beer and mashed banana $\left(\mathrm{R}_{\mathrm{w}} \mathrm{B}_{\mathrm{e}} \mathrm{B}_{\mathrm{a}}\right)$ and (ii) red wine, white wine and sugar $\left(\mathrm{R}_{\mathrm{w}} \mathrm{W}_{\mathrm{w}} \mathrm{S}\right)$. The mixtures were prepared a week before trap setting. For each litre of mixture (made up of 50\% of each of the two liquids), 220-330 $\mathrm{g}$ of banana or $220 \mathrm{~g}$ of sugar were added. The final volume of bait per trap was about $500 \mathrm{~cm}^{3}$. Traps can be hung on trunks (1.5-2 m above ground) but also set up at canopy level $(10-20 \mathrm{~m})$ using a tree-climb slingshot (BigShot by Sherrill tree) for the launch of the "lift-up" and "pull-down" rope. Traps were checked every morning from 08:00h to 13:00h to avoid the death of individuals. Traps were activated on Monday, remained active for 4 days (i.e. surveys) and deactivated on Friday. This method is the same used for monitoring of Cerambyx cerdo (Redolfi De Zan et al. 2017).

\section{Sampling plan}

The methods were tested in two areas: Bosco della Fontana (hereafter: BF; Mantova, Lombardy; coordinates: $45.200299^{\circ} \mathrm{N}, 10.740841^{\circ} \mathrm{E}$ ) (Figure 9) and Foresta della Lama (hereafter, FL; Bagno di Romagna, Emilia-Romagna; coordinates: $43.8311^{\circ} \mathrm{N}$, $11.8379^{\circ} \mathrm{E}$ ) (Figure 10 ). BF is a small fragment of lowland hornbeam-oak forest, at 25 $\mathrm{m}$ a.s.l. FL is part of a wide system of mountain deciduous forest, dominated by beech and other broadleaf trees, ranging from $600 \mathrm{~m}$ to $1,800 \mathrm{~m}$ a.s.l. (transects were located about $700 \mathrm{~m}$ a.s.l. whereas baited traps were set from $600 \mathrm{~m}$ to $900 \mathrm{~m}$ a.s.l.). Further details about the study areas are described by Carpaneto et al. (2017). 


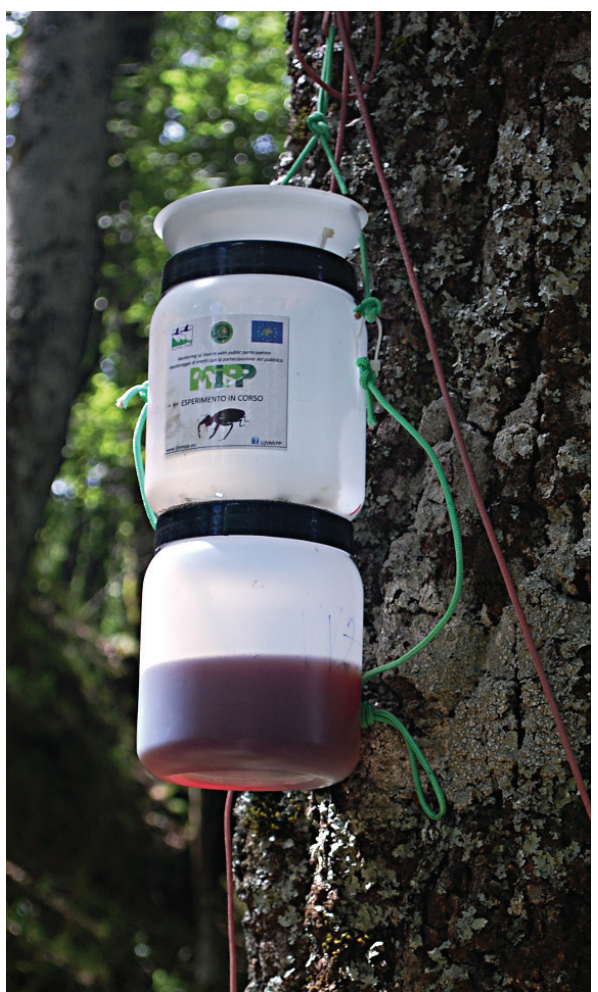

Figure 8. Baited trap for stag beetles (see construction details in the text) (photo by A. Cini).

The methods were tested from 2014 to 2016. Sightings and Remains were repeated in both study areas during the 3 years, while the method Net-transect was tested only in the last two years (Table 1). These methods were tested along the same 4 transects (Figures 9 and 10) and the transects remained the same from year to year. Each transect was monitored once a week and, in 2014, all transects were undertaken on the same day at BF. In 2015 and 2016, in both areas, monitoring methods at dusk (Sightings and Net-transect) were undertaken on the same day, along two different transects. The two methods were never perfomed at the same time on the same transect. At the end of each week, both methods were carried out for all 4 transects.

The method Net-point was undertaken only in 2014 at BF (Table 1). Four clearings (approximately circular; mean diameter: $46 \mathrm{~m}$ ) were checked in the same day, once a week, from 20:00h to 21:20h. Each clearing was checked for $15 \mathrm{~min}$. At each survey, the order of sampling of clearings changed.

Baited traps were tested in different years in the two study areas (Tables 1 and 2). In 2014, at BF, to test the attraction of the bait and trap height, 48 traps were set, arranged in eight replicates. Each replicate consisted of six traps, set in pairs on three trees. On each tree, a trap was set at canopy level on tree branches (10-20 m height; high) and another trap on the lower part of the trunk (1.5-2 m height; low). Each pair 


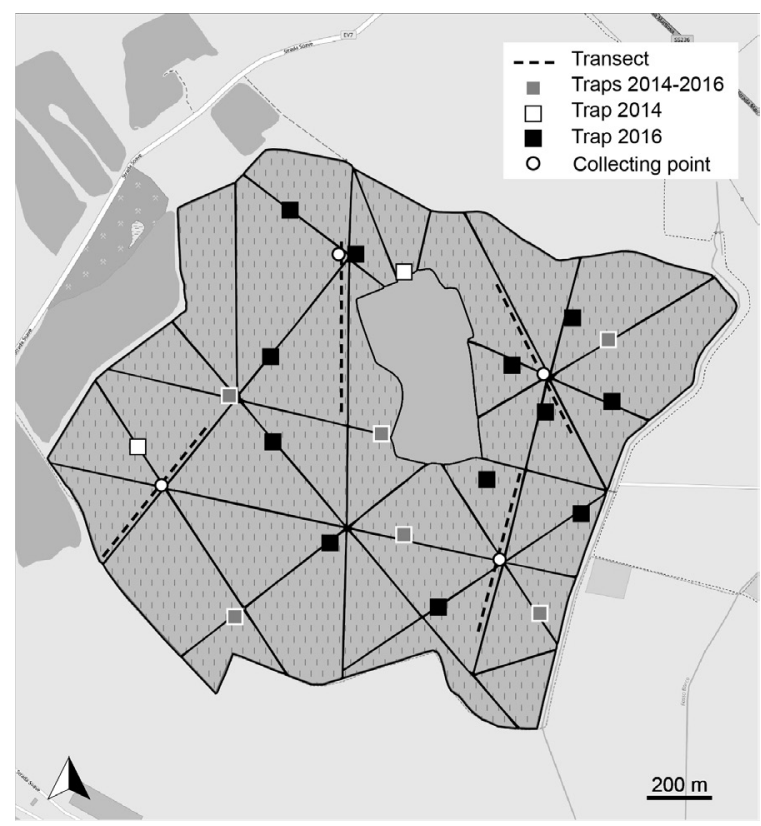

Figure 9. Map of Bosco della Fontana with the sampling sites (black dotted lines: transects for Sightings, Remains and Net-transect; white dots: clearings for Net-point; grey squares: trap sites in 2014 and 2016; black squares: trap sites in 2016; white squares: trap sites in 2014).

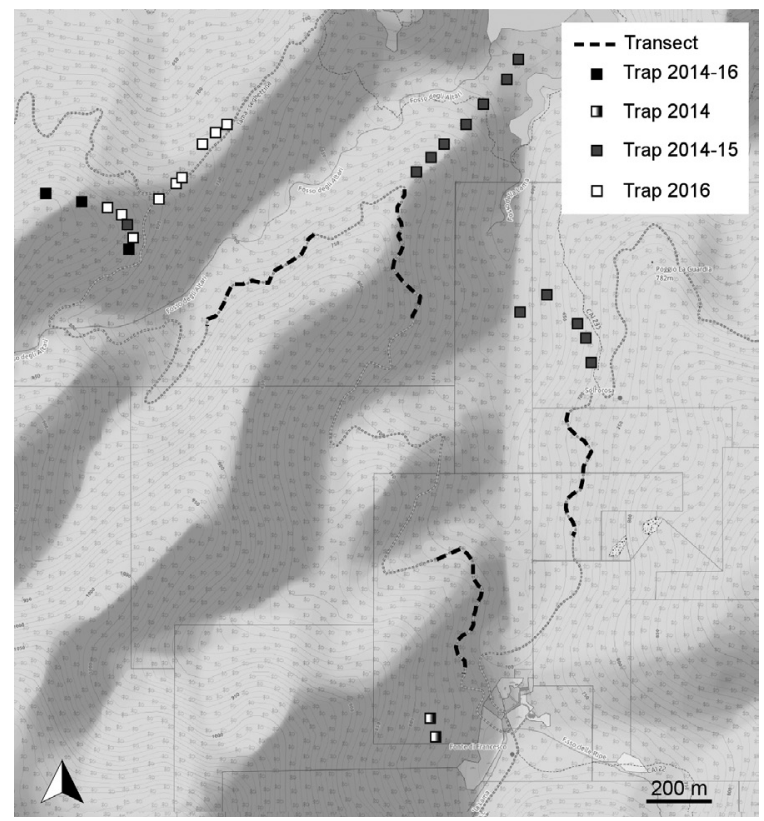

Figure 1 0. Map of Foresta della Lama with the sampling sites (black dotted lines: transects for Sightings, Remains and Net-transect; black squares: trap sites in 2014, 2015 and 2016; grey squares: trap sites in 2014 and 2015; shaded squares: trap sites in 2014; white squares: trap sites in 2016). 
Table I. Sampling plan at Bosco della Fontana (BF) and Foresta della Lama (FL) during the three years of monitoring. $\mathrm{N}=$ number of transects or traps; $\mathrm{S}=$ number of surveys; ${ }^{*}$ indicates the number of surveys per transect.

\begin{tabular}{|c|c|c|c|c|c|c|c|c|c|c|}
\hline \multirow{2}{*}{ Site } & \multirow{2}{*}{ Method } & \multicolumn{3}{|c|}{2014} & \multicolumn{3}{|c|}{2015} & \multicolumn{3}{|c|}{2016} \\
\hline & & $\mathbf{N}$ & $S$ & Dates & $\mathbf{N}$ & $S$ & Dates & $\mathrm{N}$ & $S$ & Dates \\
\hline \multirow{5}{*}{ BF } & Sightings & 4 & $10^{*}$ & $20.5-22.7$ & 4 & $8^{*}$ & $25.5-16.7$ & 4 & $6^{*}$ & $6.6-14.7$ \\
\hline & Remains & 4 & $10^{*}$ & $20.5-22.7$ & 4 & $10^{*}$ & $20.5-22.7$ & 4 & $7^{*}$ & $1.6-14.7$ \\
\hline & Net-transect & - & - & - & 4 & $8^{*}$ & $25.5-16.7$ & 4 & $6^{*}$ & $6.6-14.7$ \\
\hline & Net-point & 4 & 9 & $22.5-17.7$ & - & - & - & - & - & - \\
\hline & Baited traps & 48 & 32 & $27.5-18.7$ & - & - & - & 54 & 24 & $31.5-8.7$ \\
\hline \multirow{4}{*}{ FL } & Sightings & 4 & $7^{*}$ & $7.7-5.8$ & 4 & $7^{*}$ & $22.6-7.8$ & 4 & $5^{*}$ & $27.6-28.7$ \\
\hline & Remains & 4 & $2^{*}$ & $\begin{array}{c}6-11.7 \\
3-8.8\end{array}$ & 4 & $7^{*}$ & $22.6-7.8$ & 4 & $5^{*}$ & $29.6-27.7$ \\
\hline & Net-transect & - & - & - & 4 & $7^{*}$ & $22.6-7.8$ & 4 & $5^{*}$ & $27.6-28.7$ \\
\hline & Baited traps & 36 & 8 & $\begin{array}{c}6-11.7 \\
3-8.8\end{array}$ & 32 & 16 & $23.6-7.8$ & 24 & 20 & $28.6-29.7$ \\
\hline
\end{tabular}

Table 2. Overview of the trap sample and number of traps set in the two study areas, Bosco della Fontana (BF) and Foresta della Lama (FL), during the three years of monitoring. Baits: $\mathrm{R}_{\mathrm{w}} \mathrm{B}_{\mathrm{e}} \mathrm{B}_{\mathrm{a}}$ (Red Wine, Beer, Banana); $\mathrm{R}_{\mathrm{w}} \mathrm{W}_{\mathrm{w}} \mathrm{S}$ (Red Wine, White Wine, Sugar); Control (empty traps used as control). Height at which traps were set: High (above $10 \mathrm{~m}$ ), Low $(1.5-2 \mathrm{~m})$. Variation in ageing of the mixture: Never (mixture never changed during the season); 3 weeks (mixture changed once during the season: after three weeks); 2 weeks (mixture changed twice during the season: every 2 weeks).

\begin{tabular}{|c|c|c|c|c|c|c|c|c|}
\hline \multirow{2}{*}{ Bait } & \multirow{2}{*}{ Height } & \multirow{2}{*}{ Ageing } & \multicolumn{2}{|c|}{2014} & \multicolumn{2}{|c|}{2015} & \multicolumn{2}{|c|}{2016} \\
\hline & & & BF & FL & BF & FL & BF & FL \\
\hline \multirow{2}{*}{$\mathrm{R}_{\mathrm{w}} \mathrm{B}_{\mathrm{e}} \mathrm{B}_{\mathrm{a}}$} & High & Never & 8 & 9 & - & - & - & - \\
\hline & Low & Never & 8 & 9 & - & - & - & - \\
\hline \multirow{6}{*}{$\mathrm{R}_{\mathrm{w}} \mathrm{W}_{\mathrm{w}} \mathrm{S}$} & \multirow{3}{*}{ High } & Never & 8 & 9 & - & 16 & 18 & 12 \\
\hline & & 3 weeks & - & - & - & - & 18 & - \\
\hline & & 2 weeks & - & - & - & - & 18 & - \\
\hline & \multirow{3}{*}{ Low } & Never & 8 & 9 & - & 16 & - & - \\
\hline & & 3 weeks & - & - & - & - & - & - \\
\hline & & 2 weeks & - & - & - & - & - & 12 \\
\hline \multirow{2}{*}{ Control } & High & - & 8 & - & - & - & - & - \\
\hline & Low & - & 8 & - & - & - & - & - \\
\hline
\end{tabular}

of traps (high and low height) was baited with a different mixture: $\mathrm{R}_{w} \mathrm{~B}_{\mathrm{e}} \mathrm{B}_{\mathrm{a}}, \mathrm{R}_{\mathrm{w}} \mathrm{W}_{\mathrm{w}} \mathrm{S}_{\text {, }}$ or empty as a control. Traps were checked for eight weeks (Table 1). In 2014, at FL, 36 traps were set on 18 trees (two traps per tree) and hung at two heights as described for BF (Table 2). The baits used were the same as those set at BF but no empty traps were set (Table 2). Traps were checked for two weeks. In 2015, traps were set only at FL. The overall number of traps set was 32 on 16 trees, half of them at high height and 
the other half at low height. Traps were checked for four weeks. The only bait used was $\mathrm{R}_{\mathrm{w}} \mathrm{W}_{\mathrm{w}} \mathrm{S}$ (Table 2). In 2016 at BF, 54 traps were set, arranged in 18 replicates, each one consisting of three traps, all baited with $\mathrm{R}_{\mathrm{w}} \mathrm{W}_{\mathrm{w}} \mathrm{S}$ but with three different fermentation classes (ageing): (i) the mixture was never changed during the study season, (ii) the mixture was replaced every third week and (iii) the mixture was replaced every second week (Table 2). In 2016, at FL, the overall number of traps set was 24 on 12 trees, half of the traps at high height and half at low height. Traps were checked for five weeks. The only bait used was $\mathrm{R}_{\mathrm{w}} \mathrm{W}_{\mathrm{w}} \mathrm{S}$ (Table 2 ).

\section{Statistical analysis}

The Chi-Square test was used to detect differences between the number of females and males for each monitoring method adopted. Individuals without sex identification (i.e. Unknown) recorded during the method Sightings were not taken into account.

To compare the number of Remains with the number of Sightings, the former were considered in two ways: (i) each head found (including whole specimens) was counted as one individual (hereinafter: head counting) and (ii) the remains likely belonging to the same individual were counted as one (total counting). In addition, for the method Net-transect, the percentage of individuals collected (captures) was compared to the sum of both sighted and captured individuals (sightings+captures) along the same transect during a given survey.

Occupancy models were applied to estimate the detection probability $(\hat{p})$ of the different methods tested (Nichols et al. 2008). In particular, "single species, single season occupancy models" were used for the methods Sightings, Net-transect and Remains, whereas "single species, single season, multi-method occupancy models" were used for Baited traps. In the first case, detection probability was modelled as a constant over time $(p)$ or time-dependent $\left(p_{t}\right)$. In the second case, detection probability was modelled as constant over time and detection methods $(p)$, as time-independent but different amongst methods $\left(p^{s}\right)$, as time-dependent but constant amongst methods $\left(p_{t}\right)$ or with methods as an additive effect with time-period $\left(p_{s+t}\right)$. Small-scale occupancy $(\theta)$, which corresponds to the presence of the species at the sample station, was modelled as either time-independent $(\theta)$ or time-dependent $\left(\theta_{t}\right)$. Models were ranked in decreasing order of their values of AIC (Akaike Information Criterion) and models with $\triangle$ AIC $\leq 2$ from the top model were selected (Burnham and Anderson 2002). Analyses were carried out using the programme PRESENCE (Hines and MacKenzie 2004).

A Kruskal-Wallis test was used to compare the number of contacts between transects of the same study area, within a given sampling method: Sightings, Remains (total counting) or Net-transect (captures). These analyses were performed using STATISTICA 7.0 (StatSoft Inc.), with a significance level of 0.05 to reject the null hypothesis.

Regarding the capture performed by traps, only the datasets with sufficient captures were considered (i.e. BF 2014 and 2016; Table 3). The dataset BF 2014 was used to test the degree of attraction of the two different mixtures $\left(\mathrm{R}_{w} \mathrm{~B}_{\mathrm{e}} \mathrm{B}_{\mathrm{a}}\right.$ and $\left.\mathrm{R}_{\mathrm{w}} \mathrm{W}_{\mathrm{w}} \mathrm{S}\right)$ and 
the two heights (high and low) (the dataset BF 2014 is the same used in Bardiani et al. 2017). The dataset BF 2016 was used to test the degree of attraction of the mixture ageing (three different fermentation classes, as defined above).

\section{Results}

\section{Capture data}

At BF, Sightings and Remains (total counting) methods provided the highest number of contacts with $L$. cervus individuals for all three years (Table 3). Sightings provided the highest mean values of contacts per transect and survey (Table 3). At FL, Sightings provided the highest number of contacts during 2014-2015 (53 and 100 respectively) while, in 2016, the highest number of contacts was provided by the sum of captures and sightings carried out by the Net-transect method (Table 3). These results were confirmed by mean values (Table 3). Remains and Baited traps methods carried out at FL provided the lowest number of contacts with L. cervus (Table 3).

Head counting was $25 \%$ to $86 \%$ of the total counting, indicating that there was no constant proportionality between both ways of estimating individuals based on remains.

The percentage of individuals captured with respect to the sum of individuals sighted plus captured during the Net-transect method, varied from $0 \%$ to $100 \%$ and it was not dependent on the number of individuals sighted. The percentage of times in which the operator was able to collect all the individuals, per area and year, varied from $12 \%$ to $41 \%$.

The Chi-Square test showed a general and significant higher number of males, with the exception of Remains at FL $\left(\chi^{2}=0.266, \mathrm{P}=0.606\right)$ (Table 4).

No significant differences in number of contacts were found amongst transects for $\mathrm{BF}(\mathrm{P}=0.051$ or higher $)$ or for $\mathrm{FL}(\mathrm{P}=0.077$ or higher $)$ in any of the three sampling methods tested (Table 5).

Sightings data from BF (Figure 11) showed a peak of activity (as maximum mean value of contacts for transect and survey) at the $26^{\text {th }}$ week of the year for all three years. Compared with Sightings data, Remains data provided slightly later peaks during 2014 and 2015 (Figure 11). Compared with Sightings data, Net-transect data showed a double peak at the $25^{\text {th }}$ and $27^{\text {th }}$ week in 2015 and an earlier peak at the $25^{\text {th }}$ week in 2016.

At FL, the peak of activity shifted between the $27^{\text {th }}$ and $29^{\text {th }}$ week (Figure 12). Sightings data showed two peaks in $2014\left(27^{\text {th }}\right.$ and $29^{\text {th }}$ week $)$, one peak in 2015 ( $28^{\text {th }}$ week) and two peaks in 2016 ( $28^{\text {th }}$ and $29^{\text {th }}$ week) (Figure 12). Net-transect data provided a similar trend, with a peak at the $27^{\text {th }}$ week in both 2015 and 2016 (Figure 12). The sum of captures and sightings, both undertaken by Net-transect, showed a peak at the $28^{\text {th }}$ week (Figure 12). In all three years, Remains data (both head and total counting) never produced mean values higher than 1.0. 
Table 3. Summary of number and mean values (in brackets) of contacts ( $c=$ captures; $s=$ sightings; $s p=$ specimens; Tot = total counting; head = head counting) for each method, in the two study areas Bosco della Fontana (BF) and Foresta della Lama (FL) during the three years of monitoring.

\begin{tabular}{l|c|c|c|c|c|c|c}
\hline \multirow{2}{*}{ Method } & \multirow{2}{*}{$\begin{array}{c}\text { Contact } \\
\text { type }\end{array}$} & \multicolumn{4}{|c|}{ BF } & \multicolumn{3}{c}{ FL } \\
\cline { 3 - 8 } & & $\mathbf{2 0 1 4}$ & $\mathbf{2 0 1 5}$ & $\mathbf{2 0 1 6}$ & $\mathbf{2 0 1 4}$ & $\mathbf{2 0 1 5}$ & $\mathbf{2 0 1 6}$ \\
\hline Sightings & $\mathrm{s}$ & $156(3.9)$ & $143(4.9)$ & $195(8.1)$ & $53(2.4)$ & $100(3.6)$ & $151(7.6)$ \\
\hline $\begin{array}{l}\text { Remains } \\
\text { (Tot) }\end{array}$ & $\mathrm{sp}$ & $152(3.8)$ & $150(3.8)$ & $202(7.2)$ & $4(0.5)$ & $14(0.5)$ & $7(0.4)$ \\
\hline Remains (head) & $\mathrm{sp}$ & $87(2.2)$ & $81(2.0)$ & $146(5.2)$ & $1(0.1)$ & $12(0.4)$ & $4(0.2)$ \\
\hline Net-transect & $\mathrm{c}$ & - & $80(2.6)$ & $91(4.0)$ & - & $47(1.7)$ & $110(5.5)$ \\
\hline Net-transect & $\mathrm{c}+\mathrm{s}$ & - & $134(4.3)$ & $153(6.7)$ & - & - & $210(10.5)$ \\
\hline Net-point & $\mathrm{c}$ & 41 & - & - & - & - & - \\
\hline Baited traps & $\mathrm{c}$ & 33 & - & 103 & 1 & 4 & 9 \\
\hline
\end{tabular}

Table 4. Number of males (M), females (F) and unidentified (U) individuals contacted with different methods at Bosco della Fontana (BF) and Foresta della Lama (FL).

\begin{tabular}{c|c|c|c|c|c|c|c}
\hline Site & Method & M & F & U & DF & chi-square & P \\
\hline \multirow{4}{*}{ BF } & Sightings & 380 & 40 & 74 & 1 & 164.58 & 0.001 \\
\cline { 2 - 8 } & Remains (head) & 281 & 33 & - & 1 & 116.03 & 0.001 \\
\cline { 2 - 8 } & Net transect (captures) & 166 & 5 & - & 1 & 91.38 & 0.001 \\
\cline { 2 - 8 } & Net points (captures) & 40 & 1 & - & 1 & 23.99 & 0.001 \\
\cline { 2 - 8 } & Baited traps & 117 & 19 & - & 1 & 40.58 & 0.001 \\
\hline \multirow{4}{*}{ FL } & Sighting & 259 & 5 & 38 & 1 & 159.98 & 0.001 \\
\cline { 2 - 8 } & Remains (head) & 11 & 8 & - & 1 & 0.27 & 0.606 \\
\cline { 2 - 8 } & Net transect (captures) & 151 & 28 & - & 1 & 47.92 & 0.001 \\
\cline { 2 - 8 } & Baited traps & 14 & 1 & - & 1 & 6.98 & 0.01 \\
\hline
\end{tabular}

\section{Detection probability}

The detection probability, for all methods based on transects, was more or less dependent on time as a function of the study area and year. Overall, the detection probability for Sightings and Net-transect seemed to be more influenced by time than for Remains (Table 6).

The detection probability for Sightings and Net-transect methods was higher than 0.50 for both study areas in all three years (Figure 13). The highest detection probability for Sightings was in 2016, reaching $0.83( \pm 0.07)$ in BF and $0.85( \pm 0.08)$ in FL (Figure 13). For the method Net-transect, the highest value of detection probability was registered in 2015 at $\mathrm{BF}(0.81 \pm 0.03)$ and the lowest in 2015 at FL (0.54 \pm 0.09$)$ (Figure 13). For the method Remains, the detection probability was in general lower 
Table 5. Results of the Kruskal-Wallis test comparing the total number of contacts recorded during the 3 years (2014-2016) amongst the four transects at Bosco della Fontana (BF) and Foresta della Lama (FL), for three sampling methods (Tot $=$ total counting).

\begin{tabular}{l|c|c|c|c|c|c|c|c}
\hline \multirow{2}{*}{ Method } & \multicolumn{4}{|c|}{ BF } & \multicolumn{4}{c}{ FL } \\
\cline { 2 - 9 } & DF & N & H & P & DF & N & H & P \\
\hline Sightings & 3 & 12 & 5.974 & 0.113 & 3 & 12 & 6.843 & 0.077 \\
\hline Remains (Tot) & 3 & 12 & 7.758 & 0.051 & 3 & 12 & 2.947 & 0.400 \\
\hline Net-transect (captures) & 3 & 8 & 6.452 & 0.092 & 3 & 8 & 4.849 & 0.183 \\
\hline
\end{tabular}
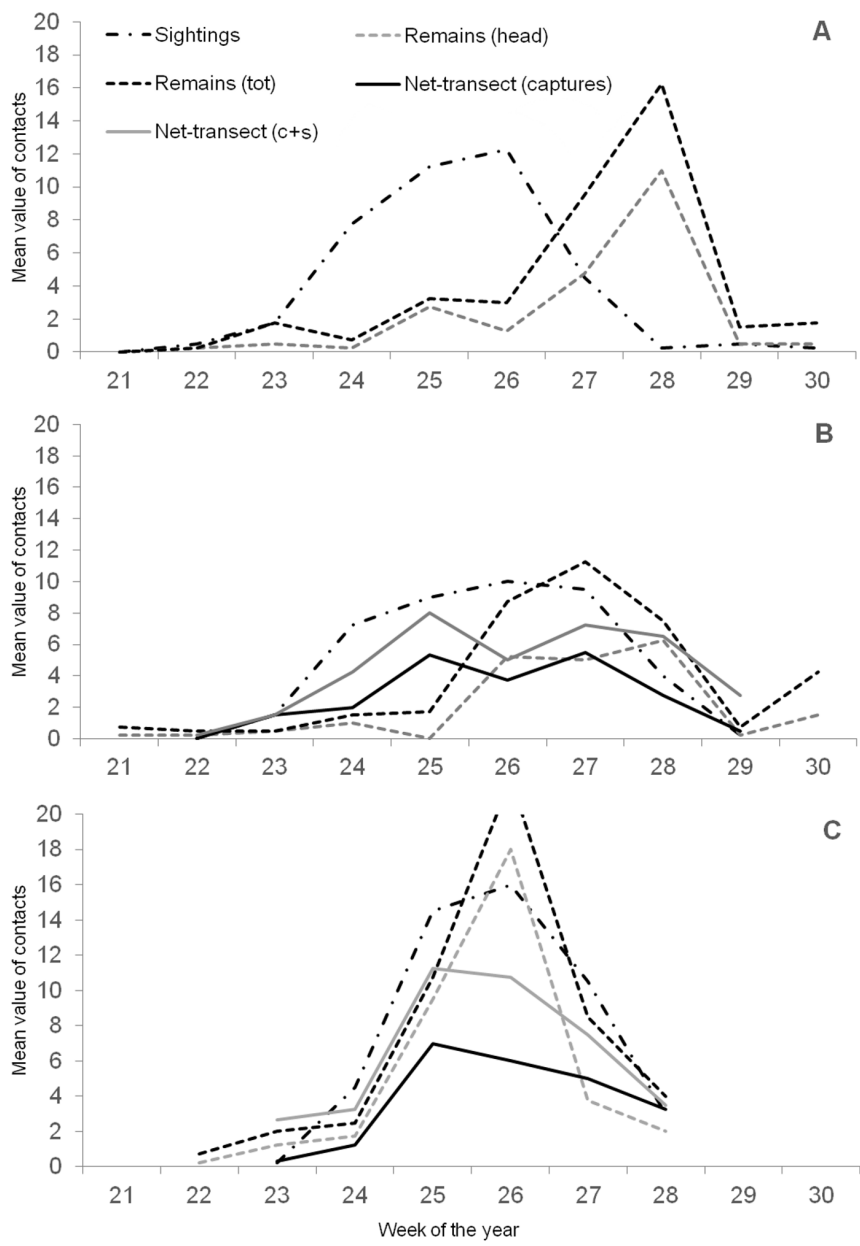

Figure I I. Phenology of the stag beetle L. cervus at Bosco della Fontana during A 2014 B 2015 C 2016. Black dashed-pointed line is the mean value of Sightings; Black dashed line is the mean value of Remains collected along transects; Grey dashed line is the mean value of Remains (heads). Black line is the mean value of captures by Net-transect; Grey line is the mean value of the sum of capture specimens and sightings performed by Net-transect. Weeks are expressed as the corresponding week of the year. The mean value of Remains at $26^{\text {th }}$ week of 2016 is 22 . 

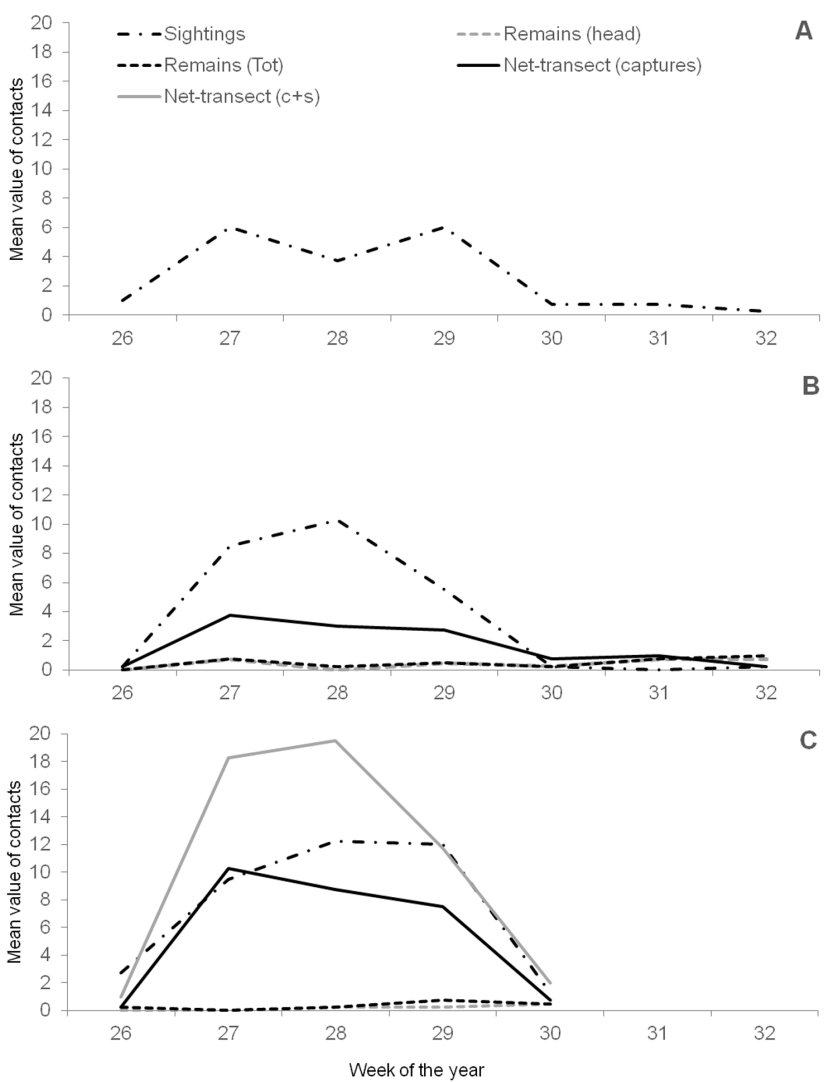

Figure 12. Phenology of the stag beetle L. cervus at Foresta della Lama during A 2014 B 2015 C 2016. Black dashed-pointed line is the mean value of Sightings; Black dashed line is the mean value of Remains collected along transects; Grey dashed line is the mean value of Remains (heads). Black line is the mean value of captures by Net-transect; Grey line is the mean value of the sum of capture specimens and sightings performed by Net-transect. Weeks are expressed as the corresponding week of the year.

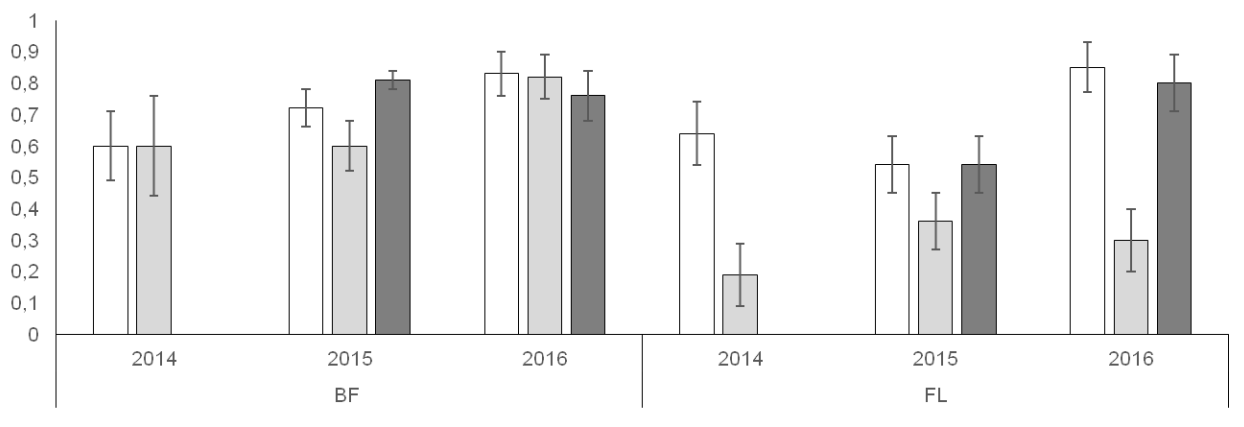

$\square$ Sightings $\quad \square$ Remains (Tot) $\quad \square$ Net-transect (Captures)

Figure 13. Detection probability values and relative standard error (SE) for the methods Sightings, Remains and Net-transect, in the two study areas Bosco della Fontana (BF) and Foresta della Lama (FL) in three years 2014-2016. 
Table 6. Summary of model selection statistics for three methods, during the seasons 2014-2016 at Bosco della Fontana (BF) and Foresta della Lama (FL). $K$ represents the number of parameters in the model and -2Log $(L)$ is twice the negative log-likelihood value. Akaike Information Criteria (AIC) and Akaike weight $(w)$ were calculated for each model. $\triangle \mathrm{AIC}$ represents the difference in AIC value relative to the top model. Detection probability $(p)$ may be constant (.) or vary amongst sampling occasions $(\mathrm{t})$.

\begin{tabular}{|c|c|c|c|c|c|c|c|c|}
\hline Site & Method & Year & Model & $K$ & $-2 \log (\mathrm{L})$ & AIC & $\Delta \mathrm{AIC}$ & $w$ \\
\hline \multirow{9}{*}{ BF } & \multirow{3}{*}{ Sightings } & 2014 & $\operatorname{psi}(),. p(\mathrm{t})$ & 11 & 23.54 & 45.54 & 0.00 & 1.00 \\
\hline & & 2015 & $\operatorname{psi}(),. p(\mathrm{t})$ & 9 & 10.04 & 28.04 & 0.00 & 1.00 \\
\hline & & 2016 & $\mathrm{psi}(),. p(\mathrm{t})$ & 7 & 9.00 & 23.00 & 0.00 & 0.79 \\
\hline & \multirow{4}{*}{$\begin{array}{c}\text { Remains } \\
\text { (Tot) }\end{array}$} & \multirow{2}{*}{2014} & $\operatorname{psi}(),. p(\mathrm{t})$ & 11 & 34.63 & 56.63 & 0.00 & 0.65 \\
\hline & & & psi(.),p(.) & 2 & 53.84 & 57.84 & 1.21 & 0.35 \\
\hline & & 2015 & psi(.),p(.) & 2 & 53.84 & 57.84 & 0.00 & 0.98 \\
\hline & & 2016 & $\operatorname{psi}(),. p()$. & 2 & 26.28 & 30.28 & 0.00 & 0.92 \\
\hline & \multirow{2}{*}{$\begin{array}{c}\text { Net-transect } \\
\text { (Captures) }\end{array}$} & 2015 & $\operatorname{psi}(),. p(\mathrm{t})$ & 9 & 5.55 & 23.55 & 0.00 & 1.00 \\
\hline & & 2016 & $\operatorname{psi}(),. p(\mathrm{t})$ & 7 & 8.32 & 22.32 & 0.00 & 0.95 \\
\hline \multirow{9}{*}{ FL } & \multirow{4}{*}{ Sightings } & 2014 & psi(.),p(.) & 2 & 28.84 & 32.84 & 0.00 & 0.84 \\
\hline & & 2015 & $\mathrm{psi}(),. p(\mathrm{t})$ & 8 & 13.50 & 29.50 & 0.00 & 1.00 \\
\hline & & \multirow{2}{*}{2016} & psi(.),p(.) & 2 & 16.91 & 20.91 & 0.00 & 0.64 \\
\hline & & & psi(.),p(t) & 6 & 10.04 & 22.04 & 1.13 & 0.36 \\
\hline & \multirow{2}{*}{$\begin{array}{c}\text { Remains } \\
\text { (Tot) }\end{array}$} & 2014 & psi(.),p(.) & 2 & 15.44 & 19.44 & 0.00 & 0.88 \\
\hline & & 2015 & psi(.),p(.) & 2 & 36.50 & 40.50 & 0.00 & 0.91 \\
\hline & \multirow{3}{*}{$\begin{array}{c}\text { Net-transect } \\
\text { (Captures) }\end{array}$} & \multirow{2}{*}{2015} & psi(.),p(.) & 2 & 38.67 & 42.67 & 0.00 & 0.66 \\
\hline & & & $\operatorname{psi}(),. p(\mathrm{t})$ & 8 & 28.04 & 44.04 & 1.37 & 0.34 \\
\hline & & 2016 & $\operatorname{psi}(),. p(\mathrm{t})$ & 6 & 9.00 & 21.00 & 0.00 & 0.82 \\
\hline
\end{tabular}

Table 7. Summary of the number of captures $(\mathrm{N})$ by baited traps and relative detection probability $(p)$ (Standard Error in brackets), for setting position of the trap (High: above $10 \mathrm{~m}$; Low: 1.5-2 m) and for the type of bait $\left(\mathrm{R}_{\mathrm{w}} \mathrm{B}_{\mathrm{e}} \mathrm{B}_{\mathrm{a}}\right.$ : Red Wine, Beer, Banana; $\mathrm{R}_{\mathrm{w}} \mathrm{W}_{\mathrm{w}} \mathrm{S}$ : Red Wine, White Wine, Sugar; Control: empty traps used as control). Change of the mixture is indicated in brackets when expected (3 weeks: changed once during the season; 2 weeks: changed twice during the season; never: never changed during the season).

\begin{tabular}{|c|c|c|c|c|c|}
\hline \multirow{2}{*}{ Setting } & \multirow{2}{*}{ Bait } & \multicolumn{2}{|c|}{2014} & \multicolumn{2}{|c|}{2016} \\
\hline & & $\mathbf{N}$ & $p(\mathrm{SE})$ & $\mathbf{N}$ & $p(\mathrm{SE})$ \\
\hline \multirow{5}{*}{ High } & Control & 0 & - & - & - \\
\hline & $\begin{array}{l}\mathbf{R}_{\mathrm{w}} \mathbf{B}_{\mathbf{e}} \mathbf{B}_{\mathbf{a}} \\
(\text { never) }\end{array}$ & 12 & $0.04(0.02)$ & - & - \\
\hline & $\begin{array}{c}\mathbf{R}_{\mathbf{w}} \mathbf{W}_{\mathbf{w}} \mathbf{S} \\
\text { (never) }\end{array}$ & 11 & $0.06(0.03)$ & 48 & $0.09(0.04)$ \\
\hline & $\begin{array}{c}\mathbf{R}_{\mathbf{w}} \mathbf{W}_{\mathbf{w}} \mathbf{S} \\
\text { (3 weeks) }\end{array}$ & - & - & 36 & $0.07(0.03)$ \\
\hline & $\begin{array}{c}\mathbf{R}_{\mathbf{w}} \mathbf{W}_{\mathbf{w}} \mathbf{S} \\
(2 \text { weeks })\end{array}$ & - & - & 19 & $0.02(0.01)$ \\
\hline \multirow{3}{*}{ Low } & Control & 0 & - & - & - \\
\hline & $\mathbf{R}_{w} B_{e} B_{a}$ & 5 & - & - & - \\
\hline & $\mathrm{R}_{\mathrm{w}} \mathrm{W}_{\mathrm{w}} \mathrm{S}$ & 5 & - & - & - \\
\hline
\end{tabular}


and more variable than for the other two methods based on transects. The lowest value for this method was registered at FL in $2014(0.19 \pm 0.10)$ and the highest value at BF in 2016 (0.82 \pm 0.07$)$ (Figure 13).

For traps, in 2014 the model showing more support was the one in which the detection probability was different amongst the methods (i.e. different mixtures) but not dependent on time (Bardiani et al. 2017). In 2016, the more supported model was the one with the detection probability depending on both method (i.e. different ageing) and time period with an additive effect.

In 2014, traps set at high height, performed better than traps set at low height at capturing individuals and also allowed the evaluation of the detection probability (Table 7) (Bardiani et al. 2017). In addition, traps baited with $\mathrm{R}_{\mathrm{w}} \mathrm{W}_{\mathrm{w}} \mathrm{S}$ showed a detection probability a little higher than those baited with $\mathrm{R}_{\mathrm{w}} \mathrm{B}_{\mathrm{e}} \mathrm{B}_{\mathrm{a}}$ (Table 7).

In 2016, only traps baited with $\mathrm{R}_{\mathrm{w}} \mathrm{W}_{\mathrm{w}} \mathrm{S}$ were used. Traps set at the beginning of the study period with no substitution of the bait, provided the highest detection probability (Table 7).

\section{Discussion}

\section{The standard method for the monitoring of Lucanus cervus}

At BF, the methods Sightings and Remains (total counting) were those which provided higher values for the total and mean number of contacts per transect and survey. Nettransect captures were lower than Sightings contacts (and the earlier Net-point method provided even less contacts). This result is expected because it was impossible to collect all the individuals sighted with a net (e.g. due to the height of flight of many individuals, to the expertise of the operator or even to the topography and characteristics of the transect). In fact, if sighted individuals (i.e. not captured but sighted) are counted with the captures (Net-transect captures+sighting), the number of contacts was close to the one provided by the Sightings method. The same patterns were found at FL, except that the Remains method provided a very low number of contacts. The Baited traps method provided the lowest number of captures compared with methods undertaken by Net, Remains or Sightings.

Sighting and Net-transect methods had sufficient time resolution to detect the peak of the activity for the species in both study areas, while Remains provided a peak only for BF but not for FL. The peak of activity was earlier at BF in the lowlands, than at FL in a mountainous area. This difference in phenology is supported by a citizen science approach, through the three years' study on the five saproxylic beetles of the MIPP (Campanaro et al. 2017). Both approaches also showed a longer adult activity period in the lowlands, compared with the mountainous areas.

All five methods tested showed a detection bias towards males. For transects at dusk, this is in line with others studies (Campanaro et al. 2016) and it was expected due to the less elusive character of the males and their propensity to fly at dusk, as supported by a recent radiotelemetry study carried out at BF (Tini et al. in press). Only 
the Remains method undertaken at FL showed no differences in sex detection, but this may be due to the very low number of contacts provided.

For Sightings and Net-transect methods, no significant difference was found in the number of contacts performed between the transects of a study area. This means that all transects were equally representative of the population and four transects were sufficient to carry out monitoring for the species in contrasting study areas: an isolated fragment of lowland forest (e.g. BF) and a large montane forest (e.g. FL). On the contrary, the statistical results obtained by the Remains method at BF, should be considered significant, if supported by inhomogeneous distribution of the remains in the study area reported by Campanaro et al. (2011b). This means that the number of remains collected was affected by the choice of the transects, thus not all transects were really representative of the population. The result obtained by Remains at FL might seem to be in contrast with the previous consideration. In reality, the number of remains collected was too low to emerge as a real difference for the representation of the population for each transect.

At $\mathrm{BF}$, all three transect-based methods provided high detection probability values. By contrast, baited traps showed a much lower detection probability even with the best bait and the high sampling effort. At FL, Sighting and Net-transect provided the highest values of detection probability while the Remains method performed much worse. This could be due to the fact that FL is a much more extended area than BF and the populations of $L$. cervus, as well as the populations of birds preying on it, can be spread in a more extended area. Data from Baited traps did not provide a suitable detection probability value because captures were extremely low. Furthermore, in this study area, Baited traps presented an additional problem: the capture chamber was often occupied by dormice (Glis glis) (Figure 14). In both study areas, the detection probability values obtained for transect methods were highest in 2016. This increase is explained by the fact that, in 2016, the sampling effort was concentrated around the peak of activity and only few surveys without sightings were recorded (almost all surveys without data occurred in 2014 and 2015 at the beginning of the season).

In conclusion, Sighting individuals along transects at dusk allows a large amount of contacts and higher detection probability values in different natural areas. The method is very cheap in terms of cost and time but certainly it needs skilled operators able to recognise the stag beetle without capture; furthermore it should be applied in an area with a definite $L$. cervus population. The use of a net to perform these transects, solves the identification problem but it reduces the number of contacts (captures) which depends on different factors (operator abilty, height of beetle flight). The captures+sightings counting should increase the number of contacts but the identification problem partially remains and, in comparison, the Sighting method is cheaper and faster than Net-transect. Collecting remains along transects is also cheaper and faster and does not need to be undertaken in the evening but, in the authors' opinion, there are several problems related to the influence of the predation rate on the final result. The use of Baited traps, which provided useful ecological data (e.g. vertical use of space), seems to be the less suitable method as the advantage of being performed during daytime does not compensate for the low number of contacts provided, the 


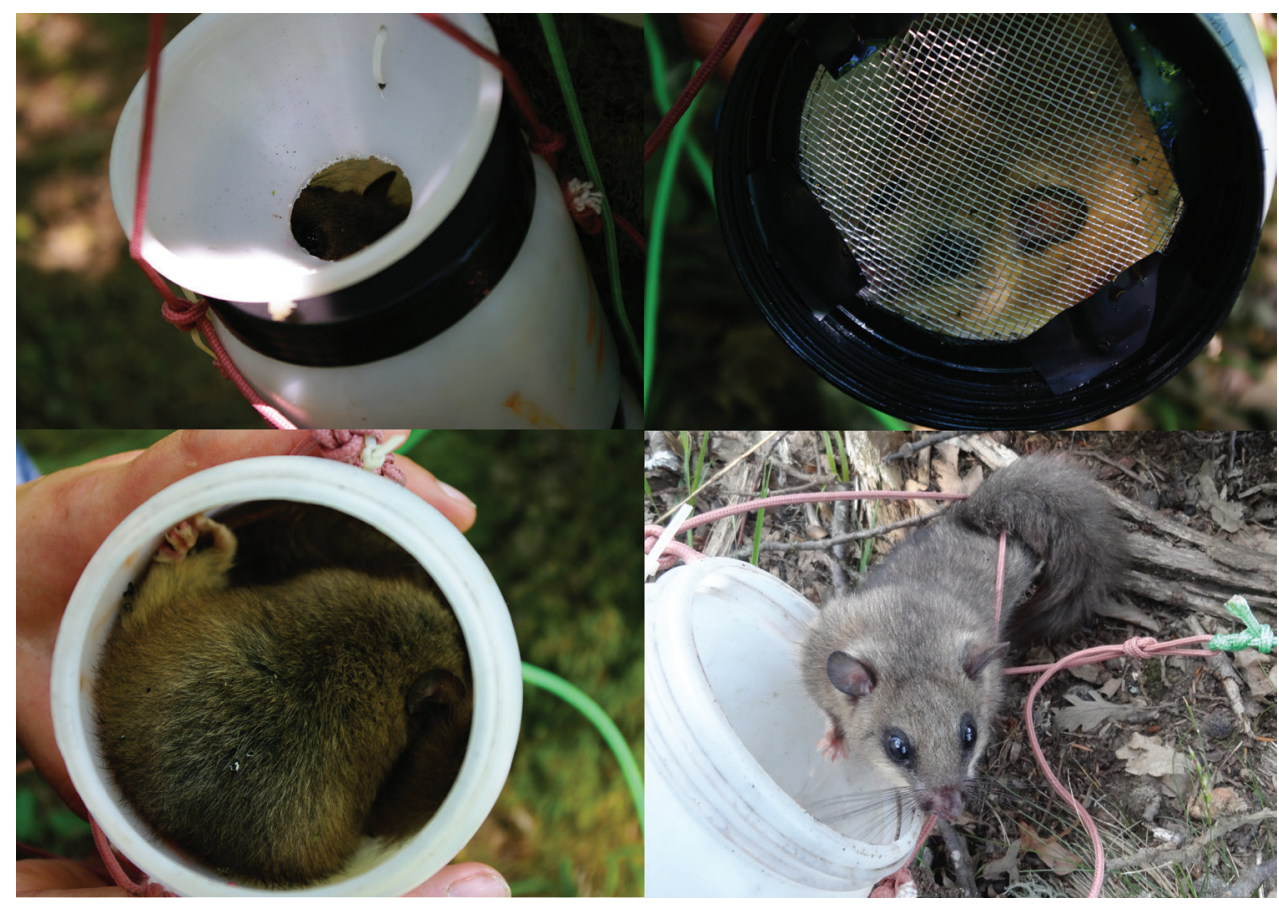

Figure I4. Dormouse captured in a baited trap at Foresta della Lama (2 July 2015). The photographs show that the animal survived in the trap due to the metallic net fixed between the bait chamber and the capture chamber (Photos by M. Bardiani and J. Röder).

high frequency of monitoring required (daily instead of weekly) and the time spent for each session (about 4 hours per day for at least 2 operators, instead of 1 hour for a transect survey). Furthermore, the low detection probability values suggested a massive sampling effort which is difficult to maintain.

Without doubt, the method Sighting individuals along transects at dusk results is the most suitable standard monitoring method for L. cervus, in terms of cost and results obtained. Collecting remains of predation along transects and Capturing individuals along transects at dusk should be taken into account during preliminary surveys of areas where information about the presence of the stag beetle is not available or in overlapping areas between two or more Lucanus species. Only when other species, like flower-chafer (Bardiani et al. 2017) or Longhorn-beetles (Redolfi De Zan et al. 2017), have to be monitored in addition to the stag beetle, the use of baited traps could also be considered for L. cervus (Bardiani et al. 2017).

\section{Description of the method}

The monitoring method consists of walking at dusk, along a standard length transect $(500 \mathrm{~m}$ long and $10 \mathrm{~m}$ width) and counting all the adults of stag beetle seen flying or walking on the ground. This transect is carried out by one operator, from 15 minutes 


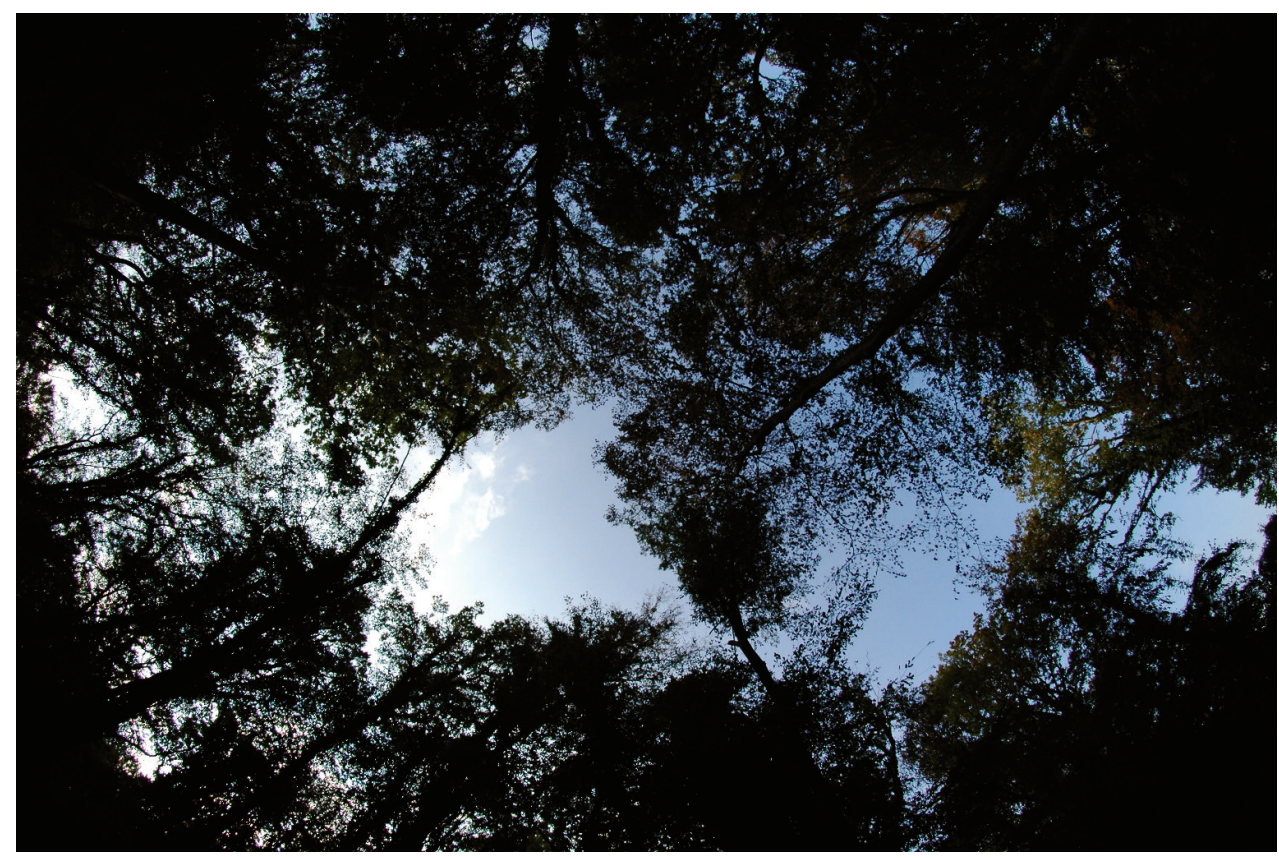

Figure I 5. Canopy cover along a transect at Bosco della Fontana (photo by M. Bardiani, APS-C camera, $8 \mathrm{~mm}$ lens).

before sunset to 15 minutes after sunset. On the whole, a transect walk lasts $30 \mathrm{~min}$ utes. The transect is divided into 5 sectors of 100 metres each and each sector should be walked in 6 minutes. Transects must be chosen along forest paths, tracks or roads with acceptable light conditions at dusk and with a suitable canopy openness (Figure 15). It is important to choose the transects only after the trees are turning green in spring and not before this period (to evaluate the real light conditions of the monitoring period). The monitoring method has to be carried out by trained operators or personnel able to recognise the stag beetle in flight.

\section{Protocol, materials and equipment}

The first step is to select the transects within the study area (up to 4 transects for a single study area), to measure the standard length of $500 \mathrm{~m}$ and to take the coordinates of the Start and End points of each one. Then, the positions of every hundred metres along the transect need to be marked with barrier tape (or other indicator: e.g. a numbered plate) on the right and left sides of the transect. The second step is to choose the weekly monitoring day for performing the surveys: (i) a single day if all the transects are checked on the same day (in this case, it is necessary to provide more than one operator) and (ii) up to 4 days if only one transect is checked per day. Setting the days is 
necessary to schedule every survey, as well as identifying the sunset time of each week (many websites, smartphone application or GPS function provide this information for specific localities or for any coordinates) and defining the walk direction of each survey. The walking direction of the transect should be inverted at every survey to reduce the possibility of sightings related to the space structure of the transect.

In total, for each transect, six surveys (i.e. six weeks) for lowland areas up to 400 $\mathrm{m}$ a.s.l. and five surveys (i.e. five weeks) for hilly and mountainous areas over $400 \mathrm{~m}$ a.s.l. are proposed. Surveys have to be chosen around the activity peak. The suggested monitoring period is between the $23^{\text {rd }}$ and $28^{\text {th }}$ week of the year for lowland areas and between the $26^{\text {th }}$ and $30^{\text {th }}$ week for hilly and mountainous areas. However these periods should be adjusted according to previous knowledge about stag beetle populations at the local level. If no direct information is available on the flying activity of stag beetles at local level, a preliminary study should be conducted in the year previous to starting the survey to obtain data on climatic conditions, extended sampling period and direct observation of stag beetle activities.

Just before starting the survey, the first part of the field-sheet (modified from Campanaro et al. 2016; see Suppl. material 1: field-sheet) must be completed (day, month, year, weather conditions, initial temperature and humidity recorded by a thermohygrometer). Fifteen minutes before the sunset time, the surveyor starts to walk. It is important to maintain a steady pace along the entire length of the transect (walking speed of $0.28 \mathrm{~m} / \mathrm{s}$ ), adjusting the walking speed by observing the hundred-metre point marks in relation to the time (to perform 100 metres every 6 minutes). For the same reason, the use of a chronometer or a wristwatch which can be easily checked during the work without distracting the observer's attention from visual hunting, is required. Every sighting is registered on the field-sheet with a letter and a number as a code indicating the sex of the beetle (using the "unknown" option when it is impossible to recognise the sex of a flying individual) and the behaviour (i.e. height of flight $<2 \mathrm{~m}$, $>2 \mathrm{~m}$ or walking individuals). With the advancing time, the light will tend to weaken and it is important to also pay attention to sounds from the vegetation at the sides of the transect to detect beetles which are flying or walking by listening for humming or rustling (on dry leaves on the ground) respectively. It is important to pay attention to individuals which fly in circles and/or back and forth from the observer. Although a certain number of 'double counted' stag beetles with a consequent over-estimation of their number in every session is already expected for this method, individuals should be counted only once.

During the transect, it is possible to encounter other species of beetles. In this case, the operator should note their presence in the field-sheet note box (while attempting to be as accurate as possible). At the end of the survey, the operator completes the field sheet with time, temperature and humidity.

In order to provide data for the National Report, which each Member State must produce in the aims of article 17 of the Habitats Directive, the monitoring should be carried out at least twice during the 6-years period. In Table 8, the main aspects of the method and protocol (including materials and equipment) have been summarised. 
Table 8. Summary of the main aspects of the monitoring method Sighting individuals along transect at dusk.

\begin{tabular}{lc}
\hline $\begin{array}{l}\text { Number of transects } \\
\text { Distance between transects }\end{array}$ & from 1 to 4 \\
Length transect & at least $200 \mathrm{~m}$ \\
$\begin{array}{l}\text { Transect subdivision } \\
\text { Monitoring period }\end{array}$ & $100 \mathrm{~m}$ \\
Number of repeats and survey weeks of the year & June-July \\
suggested (for areas up to $\mathbf{4 0 0}$ m a.s.l.) & 6 \\
Number of repeats and survey weeks of the year & $\left(23^{\text {rd }}-28^{\text {th }}\right)$ \\
suggested (for areas over $\mathbf{4 0 0}$ m a.s.1.) & 5 \\
Survey frequency (for each transect) & $\left(26^{\text {th }}-30^{\text {th }}\right)$ \\
Survey-time of the day & Once a week \\
Survey period & Dusk time \\
Number of operators & 30 min. \\
Equipment for transect design & (from 15min before to $15 \mathrm{~min}$ after sunset) \\
Survey equipment & 1 per transect \\
\hline
\end{tabular}

\section{Constraints and possible interferences}

The surveys should be carried out when the temperature is above $13^{\circ} \mathrm{C}$. The method is feasible in case of light rain and cloudy weather, but not with extremely bad weather conditions (heavy rain, strong wind). In these cases, it is better to postpone the procedure to the next evening (or at the first 'free' day, if other transects are expected during the week). If the survey cannot be postponeed, it will be cancelled.

Another issue is the lack of visibility inside the forest, especially after sunset or in the presence of a leaden sky, making it difficult to distinguish a flying stag beetle from other species with similar flight (e.g. Oryctes nasicornis, Prionus coriarius). A failure in sighting (individual not seen or misunderstood) means an under- or over-estimation of sightings. For this reason, it is highly recommended to prefer transects with an open canopy above the path and no dense undergrowth (as stag beetles tend to fly along corridors within the forests, with scarce vegetation) and to find good light conditions at the time of dusk.

In overlapping areas (where L. cervus co-exist with L. tetraodon or there are intermediate forms: see the paragraph Systematics and Distribution), the monitoring method Sighting individuals along transects at dusk should be undertaken after preliminary surveys (possibly in the former year) using other methods (i.e. Capturing individuals along transects at dusk and Collecting remains of predation along transects).

Despite the poor attraction provided by baited traps, it is highly recommended to space the transect at least $100 \mathrm{~m}$ from the nearest trap (e.g. used for monitoring of Cerambyx cerdo). 
Furthermore, mist-nets for the monitoring of birds or bats should not be set in the surrounding areas because beetles are easily entangled by nets and releasing them is very difficult and time-consuming (Carpaneto et al. 2011a).

\section{Spatial validity}

A telemetric study, conducted at BF focusing on calculating the individual home range size of the stag beetle (Tini et al. 2017b), can provide assistance in estimating the spatial validity of the selected method by understanding the dispersal ability of the species. The home range was calculated by two methods: the minimum convex polygon (MCP) and the Fixed Kernel Density Estimation (KDE). The KDE method provided measures of probability for finding an individual in a particular location (Worton 1989). The home range size did not result in being statistically different between the sexes. In particular, the MCP mean values were about $7,600 \mathrm{~m}^{2}$ for males and about $3,500 \mathrm{~m}^{2}$ for females. The median values of $\mathrm{KDE}$ with $95 \%$ probability (KDE $95 \%$ ) were about $14,500 \mathrm{~m}^{2}$ for males and $9,500 \mathrm{~m}^{2}$ for females. The $\mathrm{KDE} 50 \%$ gives information about the size of the individual core area (i.e. intensive use area) and the median values were about $3,850 \mathrm{~m}^{2}$ for males and $3,400 \mathrm{~m}^{2}$ for females. In the same study area, the median of the maximum distances (MMD) covered in a single relocation by males was $88 \mathrm{~m}$ (Tini et al. 2017b). Therefore, in homogeneous habitat conditions with high density of woody necromass and potential larval development sites (e.g. BF), the maximum survey area of the standard transect walk is: $\left(\mathrm{MMD}^{*} 2\right)^{*} \mathrm{TL}+\mathrm{MMD}^{2 *} \pi$ (Figure 16). With a standard transect length $(500 \mathrm{~m}$ long), the maximum survey area is about 11.2 ha $\left(88^{*} 2^{*} 500+88^{2 *} \pi=112,328 \mathrm{~m}^{2}\right)$.

\section{Counting, quantification and data sharing}

Quantitative information on population size, structure and dynamics is needed for assessing species extinction risk. The most common approach for obtaining detailed information on population size is to use the capture-mark-recapture method and to treat the data gathered in such a way, with parameterised mathematical models which allow the estimation of population abundance. Other recent developed modelling approaches permit: (i) an estimate of the population size of a species across the study area by only recording the presence-absence data over multiple surveys (Royle-Nichols Abundance Induced Heterogeneity model - RNAIH) (Royle and Nichols 2003) and (ii) an estimate of the population size across the study area by recording the abundance of the species over multiple surveys, without marking individuals (Royle Repeated Count model - RRC) (Royle 2004). These approaches include the use of dedicated statistical software (e.g. PRESENCE) based on complex mathematical modelling and, in some cases, have limitations that are still and continuously under development. The reviewing of specialised tools to obtain population size estimates from data gathered in 


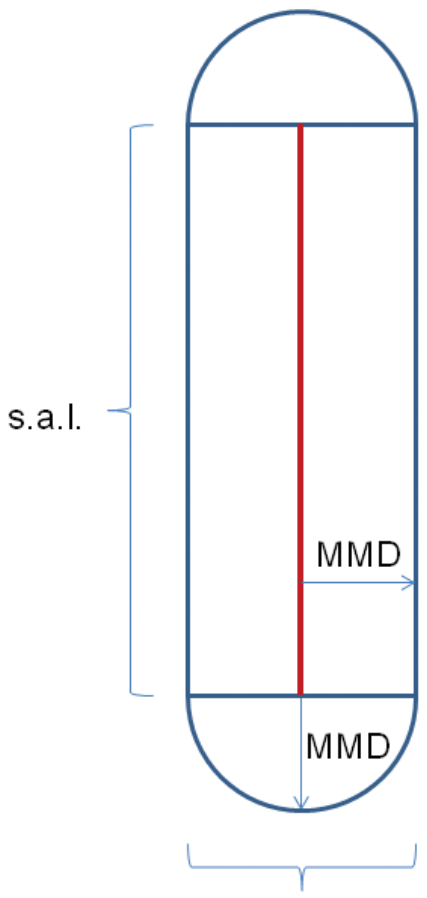

red line: line transect

blue line: survey area

MMD: median

maximum distance of

male $(88 \mathrm{~m})$

s.a.w.: survey area

width $(=2 * M M D)$

s.a.l.: survey area

lenght $(500 \mathrm{~m})$

s.a.w.

Figure 16. Graphic layout of a transect through the survey areas to show the spatial validity of the observations. MMD is the median of the maximum distance covered by a male in a single flight from the transect, as observed during the radiotelemetric fieldwork.

Table 9. Example of data summary and analysis, using the method of sightings along transect at dusk in 2016 at Bosco della Fontana. Number of sightings (Nc) for each transect (A-D) and for each Survey (1-6), total sightings and mean value for survey (Ts, Ms), total sightings and mean value for transect $(\mathrm{Tt}, \mathrm{Mt})$ and mean value of sightings for survey and transect $(\mathrm{K})$ are reported.

\begin{tabular}{|c|c|c|c|c|c|c|c|}
\hline \multirow{2}{*}{$\begin{array}{c}\text { Week of the } \\
\text { year }\end{array}$} & \multirow{2}{*}{ Survey } & \multicolumn{4}{|c|}{ Nc } & \multirow{2}{*}{ Ts } & \multirow{2}{*}{ Ms } \\
\hline & & A & B & C & D & & \\
\hline 23 & 1 & 0 & 0 & 0 & 1 & 1 & 0.25 \\
\hline 24 & 2 & 13 & 2 & 1 & 2 & 18 & 4.50 \\
\hline 25 & 3 & 21 & 18 & 6 & 13 & 58 & 14.50 \\
\hline 26 & 4 & 18 & 18 & 18 & 10 & 64 & 16.00 \\
\hline 27 & 5 & 10 & 11 & 14 & 7 & 42 & 10.50 \\
\hline 28 & 6 & 3 & 2 & 0 & 7 & 12 & 3.00 \\
\hline \multicolumn{2}{|c|}{$\mathbf{T t}$} & 65 & 51 & 39 & 40 & & \\
\hline \multicolumn{2}{|c|}{ Mt } & 10.83 & 8.50 & 6.50 & 6.67 & & \\
\hline \multicolumn{2}{|c|}{$\mathbf{K}$} & \multicolumn{4}{|c|}{8.13} & & \\
\hline
\end{tabular}


different ways, would greatly lengthen this paragraph, whose aim is instead to provide simple indications for homogeneously gathering and reporting ecological data on stag beetles obtained by the monitoring method, in data sheets shared with management authorities of protected areas. Therefore, at first it is suggested that the number of sightings (males, females, unknown sex, total) are maintained in a register for each field session, separated for each transect. Then, to obtain a value to be compared through the following years or with other study areas, the use of the mean number of sightings $(\mathrm{K})$ is encouraged. This "Key number" is the mean of sightings for each transect and for a single survey. Table 9 provides an example of stag beetle counting to obtain the K number.

\section{Acknowledgements}

We are grateful to G. Antonini, L. Benedini, S. Benelli, E. Bianchi, E. Bussola, E. Capogna, A. Cini, D. Corcos, S. Corezzola, S. Cortellessa, A. Cuccurullo, F. Dalle Pezze, V. De Aguiar, S. De Michelis, I. Di Prima, R. Fezzardi, L. Gallitelli, F. Garzuglia, P. Giangregorio, F. Grant, G. Grosso, S. Hardersen, F. Lemma, A. Leonardi, S. Khroa, F. Macina, C. Mantoni, E. Mezzadri, A. Morelli, F. Mosconi, S.G. Muñoz, G. Nardi, G. Nigro, M. Norbiato, E. Pellegrini, L. Redolfi De Zan, J. Röder, R. Rollins, S. Sabatelli, B. Sall, R. Santoro, D. Sogliani, L. Spada, V. Stagno, M. Tintoni, A. Vannini, M. Vega, M. Yslas and L. Zapponi for the fieldwork.

We would like to thank S. Bambi, L. Bartolozzi, A. Cini, I. Belousov, M. Fremlin, M. Przewoźny, C. Molls, J. Röder, U. Schmidt and M. Zilioli for allowing us to use their photographs.

We are grateful to L. Fedrigoli, F. Mazzocchi and V. Andriani (Local office of the Comando Unità Tutela Forestale Ambientale ed Agroalimentare Carabinieri UTCB of Verona), S. Bertelli, S. Marsella, B. Rossi, M. Padula, A. Zoccola and G. Quilghini (UTCB of Pratovecchio) for fieldwork and logistics. We are also grateful to M. Lo Presti and M. Tisato (UTCB of Verona) for the editing of the maps of the study areas.

A special thanks to M. Méndez and to an anonymous reviewer for their precious advice which allowed the improvement of the manuscript.

The present work was developed within the EU project LIFE11 NAT/IT/000252, with the contribution of the LIFE financial instrument of the European Union.

A special permit was obtained from the Italian Ministry of Environment for handling and capturing individuals of the target species (collection permit: Ministero dell'Ambiente e della Tutela del Territorio e del Mare - DG Protezione della Natura e del Mare, U. prot PNM 2012-0010890 del 28/05/2012).
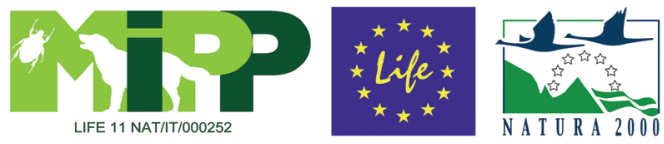

With the contribution of the LIFE financial instrument of the European Union. 


\section{References}

Allemand R, Aberlenc H-P (1991) Une méthode efficace d'echantillonage de l'entomofaune des frondaisons: le piège attractif aérien. Bulletin de la Société Entomologique Suisse 64: 293-305. Álvarez Laó CM, Álvarez Laó DJ (1995) Análisis de la mortalidad de ciervos volantes Lucanus cervus en carreteras asturianas. Boletín de Ciencias de la Naturaleza Real Instituto de Estudios Asturianos 43: 15-25.

Anonymous (2015) Operativna Programa “OKOLNA Sreda 2007-2013 G.” Proekt “Terenni prouchvaniya na razprostranenie na vidove / otsenka na sŭstoyanieto na vidove i khabitati na teritoriyata na tsyalata strana - I faza”, 1-14.

Audisio P, Baviera C, Carpaneto GM, Biscaccianti AB, Battistoni A, Teofili C, Rondinini C (Eds) (2014) Lista Rossa IUCN dei Coleotteri saproxilici Italiani. Comitato Italiano IUCN e Ministero dell'Ambiente e della Tutela del Territorio e del Mare, Roma, $1-132$.

Bardiani M, Tini M, Carpaneto GM, Audisio P, Bussola E, Campanaro A, Cini A, Maurizi E, Mason F, Sabbatini Peverieri G, Roversi PF, Toni I, Chiari S (2017) Effects of trap baits and height on stag beetle and flower chafer monitoring: ecological and conservation implications. Journal of Insect Conservation 21: 157-168. https://doi.org/10.1007/s10841-017-9965-3

Bartolozzi L (1986) Note corologiche e morfologiche sui Lucanidae in Toscana (Coleoptera). Atti Museo civico di Storia naturale di Grosseto 7/8: 11-26.

Bartolozzi L, Ghahari H, Sprecher-Uebersax E, Zilioli M (2014) A checklist of stag beetles (Coleoptera: Scarabaeoidea: Lucanidae) from Iran. Zootaxa 3887(3): 422-436. https:// doi.org/10.11646/zootaxa.3887.4.2

Bartolozzi L, Maggini L (2007) Insecta Coleoptera Lucanidae. In: Ruffo S, Stoch F (Eds) Checklist and distribution of the Italian fauna. Memorie del Museo Civico di Storia Naturale di Verona (2 $2^{\text {nd }}$ serie, Sezione Scienze della Vita) 17(2006), 191-192. [+ CD ROM]

Bartolozzi L, Norbiato M, Cianferoni F (2016b) A review of geographical distribution of the stag beetles in Mediterranean countries (Coleoptera: Lucanidae). Fragmenta entomologica 48(2): 153-168.

Bartolozzi L, Sprecher-Uebersax E (2006) Lucanidae. In: Löbl I, Smetana A (Eds) Catalogue of Palearctic Coleoptera 3. Apollo Books, Stenstrup, 63-76.

Bartolozzi L, Sprecher-Uebersax E, Bezděk A (2016a) Family Lucanidae Latreille, 1804. In: Löbl I, Löbl D (Eds) Catalogue of Palaearctic Coleoptera 3. Scarabaeoidea - Scirtoidea - Dascilloidea - Buprestoidea - Byrrhoidea. Revised and updated Edition. Brill, Leiden, Boston, 58-84.

Burnham KP, Anderson DR (2002) Model Selection and Multimodel Inference: A Practical Information-Theoretic Approach. Springer, 1-488.

Campanaro A, Bardiani M (2012) Walk transects for monitoring of Lucanus cervus in an Italian lowland forest. Studia Forestalia Slovenica 137: 17-22.

Campanaro A, Bardiani M, Spada L, Carnevali L, Montalto F, Antonini G, Mason F, Audisio P (2011a) Linee guida per il monitoraggio e la conservazione dell'entomofauna saproxilica. Quaderni Conservazione Habitat 6, Cierre Grafica, Verona, 1-8. [+ CD-ROM] 
Campanaro A, Hardersen S, Redolfi De Zan L, Antonini G, Bardiani M, Maura M, Maurizi E, Mosconi F, Zauli A, Bologna MA, Roversi PF, Sabbatini Peverieri G, Mason F (2017) Analyses of occurrence data of protected insect species collected by citizens in Italy. In: Carpaneto GM, Audisio P, Bologna MA, Roversi PF, Mason F (Eds) Guidelines for the Monitoring of the Saproxylic Beetles protected in Europe. Nature Conservation 20: 265297. https://doi.org/10.3897/natureconservation.20.12704

Campanaro A, Toni I, Hardersen S, Grasso DA (2011b) Monitoring of Lucanus cervus by means of Remains of Predation (Coleoptera: Lucanidae). Entomologia generalis 33 (1/2): 79-89. https://doi.org/10.1127/entom.gen/33/2011/79

Campanaro A, Zapponi L, Hardersen S, Méndez M, Al Fulaij N, Audisio P, Bardiani M, Carpaneto GM, Corezzola S, Della Rocca F, Harvey D, Hawes C, Kadej M, Karg J, Rink M, Smolis A, Sprecher E, Thomaes A, Toni I, Vrezec A, Zauli A, Zilioli M, Chiari S (2016) A European monitoring protocol for the stag beetle, a saproxylic flagship species. Insect Conservation and Diversity 9: 574-584. https://doi.org/10.1111/icad.12194

Carpaneto GM, Baviera C, Biscaccianti AB, Brandmayr P, Mazzei A, Mason F, Battistoni A, Teofili C, Rondinini C, Fattorini S, Audisio P (2015) A Red List of Italian Saproxylic Beetles: taxonomic review, ecological features and conservation isssues (Coleoptera). Fragmenta entomologica 47(2): 53-126. https://doi.org/10.4081/fe.2015.138

Carpaneto GM, Campanaro A, Hardersen S, Audisio P, Bologna MA, Roversi PF, Sabbatini Peverieri G, Mason F (2017) The LIFE Project "Monitoring of insects with public participation” (MIPP): aims, methods and conclusions. In: Carpaneto GM, Audisio P, Bologna MA, Roversi PF, Mason F (Eds) Guidelines for the Monitoring of the Saproxylic Beetles protected in Europe. Nature Conservation 20: 1-35. https://doi.org/10.3897/natureconservation.35.12761

Carpaneto GM, Mazziotta A, Maltzeff P (2011a) Are mist nets a menace for threatened insects? A first attempt to gather quantitative data. Journal of Insect Conservation 15: 833-837. https://doi.org/10.1007/s10841-011-9381-z

Carpaneto GM, Piattella E, Dellacasa G, Dellacasa M, Pittino R, Mazziotta A (2011b) The lamellicorn beetles of southern Sardinia (Coleoptera: Scarabaeoidea). In: Nardi G, Whitmore D, Bardiani M, Birtele D, Mason F, Spada L, Cerretti P (Eds) Biodiversity of Marganai and Montimannu (Sardinia). Research in the framework of the ICP Forest network. Conservazione Habitat Invertebrati 5: 353-387.

Chiari S, Zauli A, Audisio P, Campanaro A, Donzelli PF, Romiti F, Svensson GP, Tini M, Carpaneto GM (2014) Monitoring presence, abundance and survival probability of the stag beetle, Lucanus cervus, using visual and odour-based capture methods: implication for conservation. Journal of Insect Conservation 18: 99-109. https://doi.org/10.1007/ s10841-014-9618-8

Corezzola S, Bardiani M, Hardersen S, Spada L, Toni I (2012) Progetto di attività di monitoraggio della fauna invertebrata in attuazione del piano di gestione del Sito ITB20B0011 Bosco Fontana e definizione di protocolli di monitoraggio. Relazione finale, Mantova, 1-84.

Cortellessa S, Cianferoni F, Bartolozzi L (2014) Nuovi dati sulla distribuzione dei Lucanidi in Toscana (Coleoptera, Lucanidae). Onychium 10(2013): 68-77. 
Cox K, Thomaes A, Antonini G, Zilioli M, De Gelas K, Harvey D, Solano E, Audisio P, McKeown N, Shaw P, Minetti R, Bartolozzi L, Mergeay J (2013) Testing the performance of a fragment of the COI gene to identify western Palaearctic stag beetle species (Coleoptera, Lucanidae). In: Nagy ZT, Backeljau T, De Meyer M, Jordaens K (Eds). DNA barcoding: a practical tool for fundamental and applied biodiversity research. Zookeys 365: 105-126.

Fabbri R (2010) Segnalazioni faunistiche n. 99-102. Quaderno di Studi e Notizie di Storia Naturale della Romagna, 29 (2009): 235-236.

Fernández de Gamboa R, Garzón A (2009) Primer registro de Lucanus cervus (Linné, 1758) f. pontbrianti (Mulsant, 1839) (Coleoptera: Lucanidae) para la Península Ibérica. Boletín Sociedad Entomológica Aragonesa 44: 533-534.

Franciscolo ME (1997) Fauna d'Italia. Vol. XXXV. Coleoptera Lucanidae. Calderini Edizioni, Bologna, I-XI+1-228.

Fremlin M, Hendriks P (2011) Sugaring for stag beetles - different feeding strategies of Lucanus cervus and Dorcus parallelipipedus. Bulletin of the Amateur Entomologist's Society 70: 57-67.

Fremlin M, Hendriks P (2014) Number of instars of Lucanus cervus (Coleoptera: Lucanidae) larvae. Entomologische Berichten 74(3): 115-120.

Fremlin M, Tanahashi M (2015) Sexually-dimorphic post-eclosion behaviour in the European stag beetle Lucanus cervus (L.) (Coleoptera: Lucanidae). Bulletin de la Societe Entomologique Suisse 88: 29-38.

Fujita H (2010) The Lucanid Beetles of the World. Iconographic Series of Insects 6, Mushi-Sha, Tokyo, 1-472.

Fusu L, Stan M, Dascălu MM (2015) Coleoptera. In: Iorgu IS (Ed.) Ghid Sintetic pentru Monitorizarea Speciilor de Nevertebrate de Interes Comunitar din România, București, 44-61.

GTLI (2005) 4.4 Abundance of Lucanus cervus. Available on: http://entomologia.rediris.es/ gtli/engl/four/d/abunengl.htm

Harvey DJ, Gange AC (2006) Size variation and mating success in the stag beetle, Lucanus cervus. Physiological Entomology 31: 218-226. https://doi.org/10.1111/j.13653032.2006.00509.x

Harvey DJ, Gange AC, Hawes CJ, Rink M, Abdehalden M, Al-Fulaij N, Asp T, Ballerio A, Bartolozzi L, Brustel H, Cammaerts R, Carpaneto GM, Cederberg B, Chobot K, Cianferoni F, Drumont A, Ellwanger G, Ferreira S, Grosso-Silva J, Gueorguiev B, Harvey W, Hendriks P, Istrate P, Jansson N, Jelaska L, Jendek E, Jovic M, Kervyn T, Krenn H, Kretschmer K, Legakis A, Lelo S, Moretti M, Merkl O, Mader D, Palma R, Neculiseanu Z, Rabitsch W, Rodriguez S, Smit J, Smith M, Sprecher-Uebersax E, Telnov D, Thomaes A, Thomsen P, Tykarski P, Vrezec A, Werner S, Zach P (2011a) Bionomics and distribution of the stag beetle, Lucanus cervus (L) across Europe. Insect Conservation and Diversity 4: 23-38. https://doi.org/10.1111/j.1752-4598.2010.00107.x

Harvey DJ, Hawes CJ, Gange AC, Finch P, Chesmore D, Farr I (2011b) Development of noninvasive monitoring methods for larvae and adults of the stag beetle, Lucanus cervus. Insect Conservation and Diversity 4: 4-14. https://doi.org/10.1111/j.1752-4598.2009.00072.x 
Hawes CJ (2005) The Stag Beetle Lucanus cervus (L.) (Coleoptera: Lucanidae) in the County of Suffolk (England): Distribution and Monitoring. Proceedings of the $3^{\text {rd }}$ Symposium and Workshop on the Conservation of Saproxylic Beetles, Riga/Latvia, $7^{\text {th }}-11^{\text {th }}$ July 2004: 51-67.

Hawes CJ (2008) The stag beetle Lucanus cervus (Linnaeus, 1758) (Coleoptera: Lucanidae): a mark-release-recapture study undertaken in one United Kingdom residential garden. Revue d'Ecologie, Terre vie, 63: 131-138.

Hendriks P, Fremlin M (2012) How stag beetles pupate. http://maria.fremlin.de/stagbeetles/ pupation/pupation_captivity.html.

Hines JE, MacKenzie DI (2004) PRESENCE, version 5.3 http://www.mbr-pwrc.usgs.gov/software.html

Jansson N (2011) Attraction of stag beetles with artificial sap in Sweden. Bulletin of the Amateur Entomologist's Society 70: 51-56.

Kervyn T (2006). Cerf-volant, lucane. In: Goffart P (Ed.) Cahiers "Natura 2000": Especes de l'Annexe II de la Directive Habitat presentes en Wallonie, CRNFB, Gembloux, 42-44.

Lapiana F, Sparacio I (2006) I Coleotteri Lamellicorni delle Madonie (Sicilia) (Insecta Coleoptera Lucanoidea et Scarabaeoidea). Naturalista siciliano (S. IV) 30(2): 227-292.

Malchau W (2006) Kriterien zur Bewertung des Erhaltungszustandes der Populationen des Hirskäfers Lucanus cervus (Linnaeus, 1778). In: Schnitter P, Eichen C, Ellenwanger G, Neukirchen M, Schröder E (Eds) Empfehlungen für die Erfassung und Bewertung von Arten als Basis für das Monitoring nach Artikel 11 und 17 der FFH-Richtlinie in Deutschland. Berichte des Landesamtes für Umweltschutz Sachsen-Anhalt (Halle), Sonderheft 2: 153-154.

Mason F, Cerretti P, Tagliapietra A, Speight MCD, Zapparoli M (2002) Invertebrati di una foresta della Pianura Padana, Bosco della Fontana, Primo contributo. Conservazione Habitat Invertebrati 1. Gianluigi Arcari Editore, Mantova, 1-176.

Mason F, Roversi PF, Audisio P, Bologna MA, Carpaneto GM, Antonini G, Mancini E, Sabbatini Peverieri G, Mosconi F, Solano E, Maurizi E, Maura M, Chiari S, Sabatelli S, Bardiani M, Toni I, Redolfi De Zan L, Rossi de Gasperis S, Tini M, Cini A, Zauli A, Nigro G, Bottacci A, Hardersen S, Campanaro A (2015) Monitoring of insects with public participation (MIPP; EU LIFE project 11 NAT/IT/000252): overview on a citizen science initiative and a monitoring programme (Insecta: Coleoptera; Lepidoptera; Orthoptera). Fragmenta entomologica 47(1): 51-52. https://doi.org/10.4081/fe.2015.134

Miksic R (1959a) Beitrag zur Kenntnis der Lamellicornia-fauna der Apenninen. II. Campanische Apenninen. Memorie del Museo Civico di Storia Naturale di Verona 7: 287-295.

Miksic R (1959b) Beitrag zur Kenntnis der Lamellicornen-Fauna der Apenninen. Ricerche zoologiche sul massiccio del Pollino, 29, Coleoptera 15. Annali dell'Istituto e Museo di Zoologia dell'Università di Napoli 11: 1-24.

Miksic R (1961) Beitrag zur Kenntnis der Lamellicornia-fauna der Apenninen. IV. Aspromonte. Memorie del Museo Civico di Storia Naturale di Verona 9: 5-25.

Moretti M, Sprecher-Uebersax E (2004) Über das Vorkommen des Hirschkäfers Lucanus cervus (Coleoptera, Lucanidae) im Tessin: Eine Umfrageim Sommer 2003. Mitteilungen der Entomologischen Gesellschaft Basel 54: 75-82.

Nichols JD, Bailey LL, O’Connell AF Jr., Talancy NW, Campbell Grant EH, Gilbert AT, Annand EM, Husband TP, Hines JE (2008) Multi-scale occupancy estimation and modelling 
using multiple detection methods. Journal of Applied Ecology 45: 1321-1329. https://doi. org/10.1111/j.1365-2664.2008.01509.x

Nieto A, Alexander KNA (2010) European Red List of Saproxylic Beetles. Publications Office of the European Union, Luxemburg, 1-56.

Percy C, Bassford G, Keeble V (2000). Findings of the 1998 National Stag Beetle Survey. London, People's Trust for Endangered Species, London, 1-46.

Proyecto Ciervo Volante (1995) Proyecto ciervo volante. Boletín de la Sociedad Entomológica Aragonesa 11: 41-44.

Redolfi De Zan L, Bardiani M, Antonini G, Campanaro A, Chiari S, Mancini E, Maura M, Sabatelli S, Solano E, Zauli A, Sabbatini Peverieri G, Roversi PF (2017) Guidelines for the monitoring of Cerambyx cerdo. In: Carpaneto GM, Audisio P, Bologna MA, Roversi PF, Mason F (Eds) Guidelines for the Monitoring of the Saproxylic Beetles protected in Europe. Nature Conservation 20: 129-164. https://doi.org/10.3897/natureconservation.20.12703

Rink M, Sinsch U (2007) Radio-telemetric monitoring of dispersing stag beetles: implications for conservation. Journal of Zoology 272: 235-243. https://doi.org/10.1111/j.14697998.2006.00282.x

Rink M, Sinsch U (2011) Warm summers negatively affect duration of activity period and condition of adult stag beetles (Lucanus cervus). Insect Conservation and Diversity 4: 15-22. https://doi.org/10.1111/j.1752-4598.2009.00073.x

Romiti F, Redolfi De Zan L, Piras P, Carpaneto GM (2016) Shape variation of mandible and head in Lucanus cervus (Coleoptera: Lucanidae): a comparison of morphometric approaches. Biological Journal of the Linnean Society. https://doi.org/10.1093/biolinnean/blw001

Romiti F, Tini M, Redolfi De Zan L, Chiari S, Zauli A, Carpaneto GM (2015) Exaggerated allometric structures in relation to demographic and ecological parameters in Lucanus cervus (Coleoptera: Lucanidae). Journal of Morphology 276(10): 1193-1204. https://doi. org/10.1002/jmor.20411

Royle JA (2004) N-mixture models for estimating population size from spatially replicated counts. Biometrics 60: 108-115. https://doi.org/10.1111/j.0006-341X.2004.00142.x

Royle JA, Nichols JD (2003) Estimating abundance from repeated presence-absence data or point counts. Ecology 84: 777-790. https://doi.org/10.1890/0012-9658(2003)084[0777:EAF RPA]2.0.CO;2

Santoro F, Pivotti I, D’Allestro V, Fabrizi A, Di Veroli A, Di Giovanni MV, Corallini C, Mandrioli M, Goretti E (2009) Lucanus cervus e Lucanus tetraodon (Coleoptera - Lucanidae) in Umbria. Bollettino del Museo e Istituto di Biologia dell'Università di Genova 71: 202.

Smit JT, Krekels RFM (2006) Vliegend hert in Limburg Actieplan 2006-2010. EIS-Nederland en Bureau Natuurbalans-Limes duvergens; Leiden-Nijmegen/Nederland.

Smith MN (2003) National stag beetle survey 2002. People's Trust for Endangered Species, London, 1-14.

Smith MN (2011) Great Stag Hunt III: National stag beetle survey 2006 - 2007. People’s Trust for Endangered Species, London, 1-23.

Solano E, Thomaes A, Cox K, Carpaneto GM, Cortellessa S, Baviera C, Bartolozzi L, Zilioli M, Casiraghi M, Audisio P, Antonini G (2016) When morphological identification meets genetic 
data: the case of Lucanus cervus and L. tetraodon (Coleoptera, Lucanidae). Journal of Zoological Systematics and Evolutionary Research 54: 197-205. https://doi.org/10.1111/jzs.12124

Sprecher-Uebersax E, Durrer H (1998) Über das Vorkommen des Hirschkäfers (Lucanus cervus L.) in der Region Basel. Mitteilungen der Entomologischen Gesellschaft Basel 48(4): 142-166.

Tanashi M, Kubota K, Matsushita N, Togashi K (2010) Discovery of mycangia and associated xylose-fermenting yeasts in stag beetles (Coleoptera: Lucanidae). Naturwissenschaften 97: 311-317. https://doi.org/10.1007/s00114-009-0643-5

Thomaes A (2008) Onderzoek en monitoring van het Vliegend hert [Study and Monitoring of the Stag Beetle]. Instituut Natuur-en Bosonderzoek, INBO.R.2008.2, Brussel, Belgium.

Tini M, Bardiani M, Campanaro A, Mason F, Audisio PA, Carpaneto GM (2017a) Detection of stag beetle oviposition sites by combining telemetry and emergence traps. In: Campanaro A, Hardersen S, Sabbatini Peverieri G, Carpaneto GM (Eds) Monitoring of saproxylic beetles and other insects protected in the European Union. Nature Conservation 19: 81-96. https://doi.org/10.3897/natureconservation.19.12678

Tini M, Bardiani M, Chiari S, Campanaro A, Maurizi E, Toni I, Mason F, Audisio PA, Carpaneto GM (2017b) Use of space and dispersal ability of a flagship saproxylic insect: a telemetric study of the stag beetle (Lucanus cervus) in a relict lowland forest. Insect Conservation and Diversity. https://doi.org/10.1111/icad.12260

Tini M, Bardiani M, Campanaro A, Mason F, Audisio PA, Carpaneto GM (in press) A stag beetle's life: sex-related differences in daily activity and behaviour of Lucanus cervus (Coleoptera: Lucanidae). Journal of Insect Conservation.

Trizzino M, Audisio P, Bisi F, Bottacci A, Campanaro A, Carpaneto GM, Chiari S, Hardersen S, Mason F, Nardi G, Preatoni DG, Vigna Taglianti A, Zauli A, Zilli A, Cerretti P (2013) Gli artropodi italiani in Direttiva Habitat: biologia, ecologia, riconoscimento e monitoraggio. Quaderni Conservazione Habitat 7. Cierre Grafica, Sommacampagna, Verona, 1-256.

Tronquet M (2014) Catalogue des Coléoptères de France. Revue de l'Association Roussillonaise d'Entomologie 23(Suppl.): 1-1052.

Vrezec A (2008) Phenological estimation of imagos occurrence in four saproxylic beetle species of conservation importance in Slovenia: Lucanus cervus, Cerambyx cerdo, Rosalia alpina, Morinus funereus (Coleoptera: Lucanidae, Cerambycidae). Acta Entomologica Slovenica 16: 117-126.

Vrezec A, Ambrožič Š, Kapla A (2012) Supplementary studies of Natura 2000 species and monitoring of selected beetle species in year 2012: Carabus variolosus, Lucanus cervus, Rosalia alpina, Rosalia alpina, Morimus funereus, Graphoderus bilineatus. Final Report - Nationalni inštitut za biologijo, Ljubljana.

Vrezec A, Kapla A (2007) Quantitative beetle (Coleoptera) sampling in Slovenia: a reference study. Acta entomologica Slovenica 15: 131-160.

Worton BJ (1989) Kernel methods for estimating the utilization distribution in home-range studies. Ecology 70: 164-168. https://doi.org/10.2307/1938423

Zapponi L, Cini A, Bardiani M, Hardersen S, Maura M, Maurizi E, Redolfi De Zan L, Audisio P, Bologna MA, Carpaneto GM, Roversi PF, Sabbatini Peverieri G, Mason F, Campanaro A (2017) Citizen science data as an efficient tool for mapping protected 
saproxylic beetles. Biological Conservation 208: 139-145. https://doi.org/10.1016/j. biocon.2016.04.035

Zilioli M, Pittino R (2004) Un reperto eccezionale: Lucanus tetraodon Thunberg in Lombardia

(Coleoptera, Lucanidae). Atti della Società Italiana di Scienze Naturali e del Museo Civico di Storia Naturale in Milano 145(2): 301-306.

\section{Supplementary material I}

\section{Field sheet}

Authors: Marco Bardiani, Stefano Chiari, Emanuela Maurizi, Massimiliano Tini, Ilaria Toni, Agnese Zauli, Alessandro Campanaro, Giuseppe Maria Carpaneto, Paolo Audisio Data type: field sheet

Explanation note: Field sheet to be compiled during each survey, for each transect. Each sighting is registered with a code, in the exact point of detection along the transect (path). Codes are reported on the right column of the field-sheet. Examples of codes: male in flight over $2 \mathrm{~m}-\mathrm{M} 2$; female walk on the ground - F0; L. cervus with uncertain sex-determination, in flight below $2 \mathrm{~m}-\mathrm{U} 1$.

Copyright notice: This dataset is made available under the Open Database License (http://opendatacommons.org/licenses/odbl/1.0/). The Open Database License $(\mathrm{ODbL})$ is a license agreement intended to allow users to freely share, modify, and use this Dataset while maintaining this same freedom for others, provided that the original source and author(s) are credited.

Link: https://doi.org/10.3897/natureconservation.20.12687.suppl1 